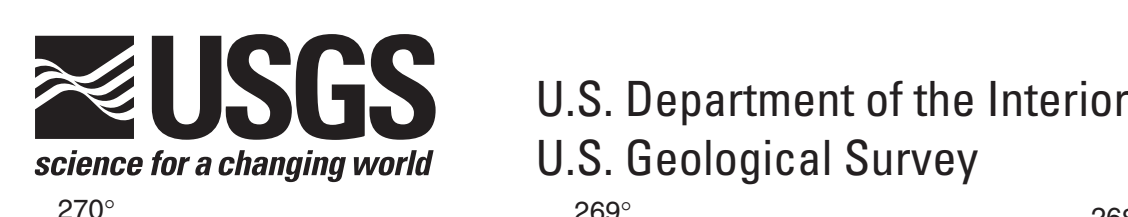

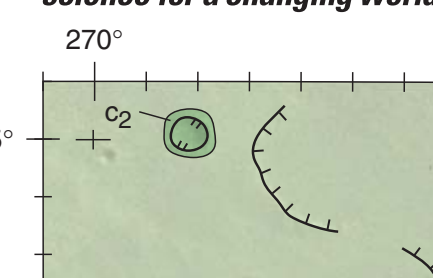

$\mathbb{Q}_{a}^{\omega_{2}}$

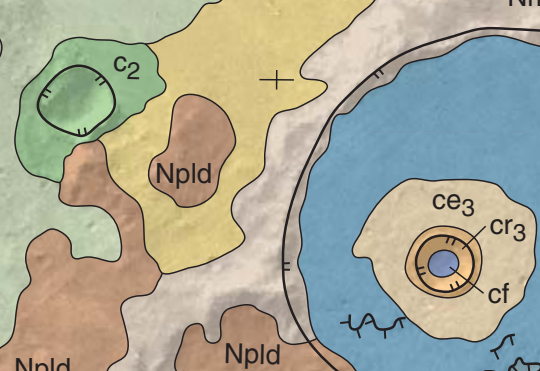

e:

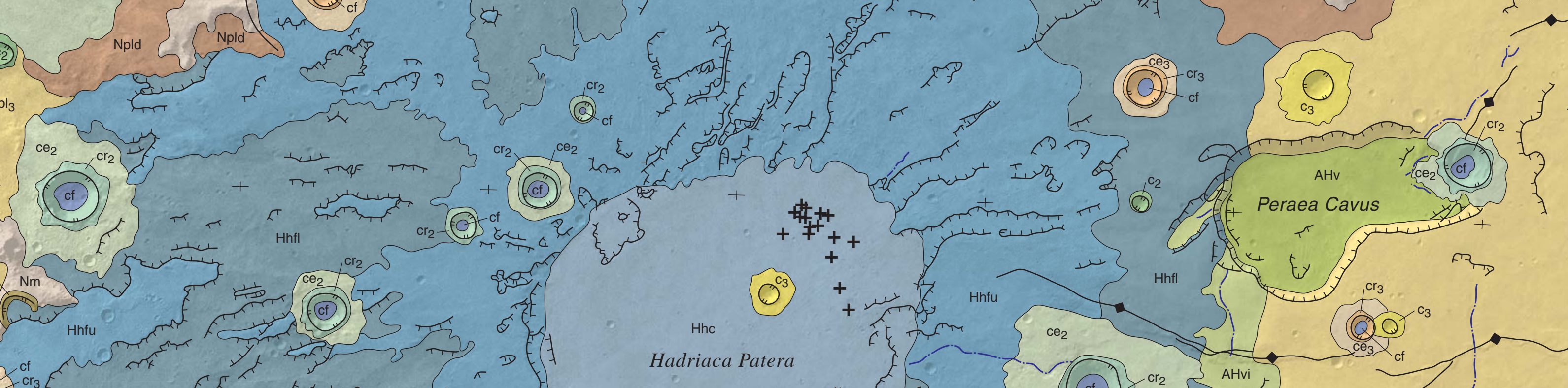

$\infty$

3.

2) Jol

6) 10 (1)
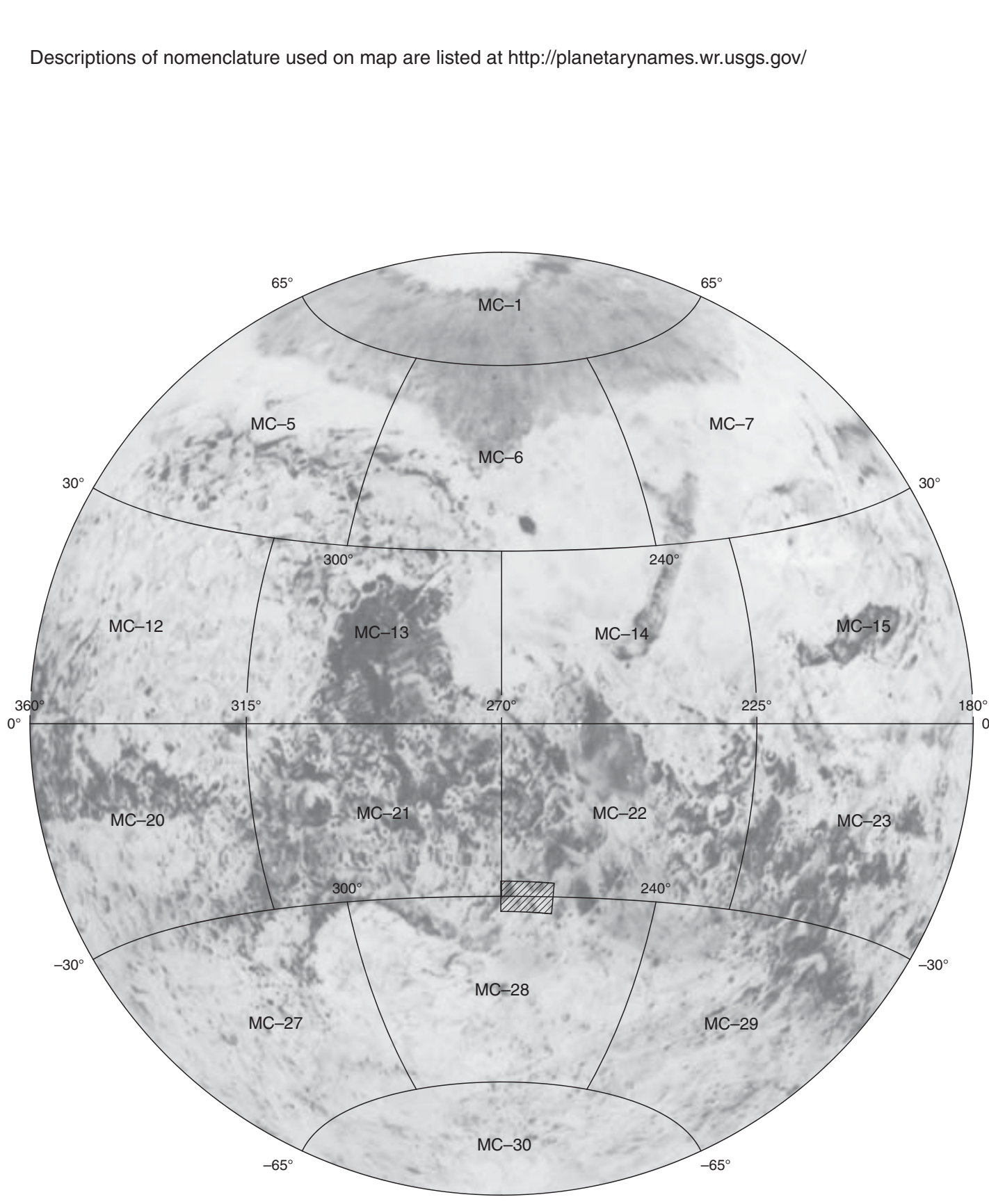

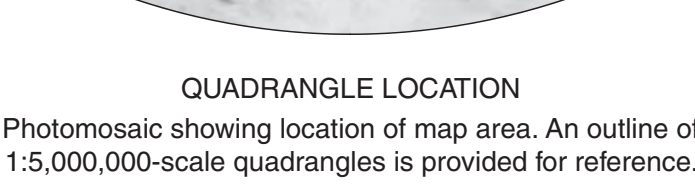

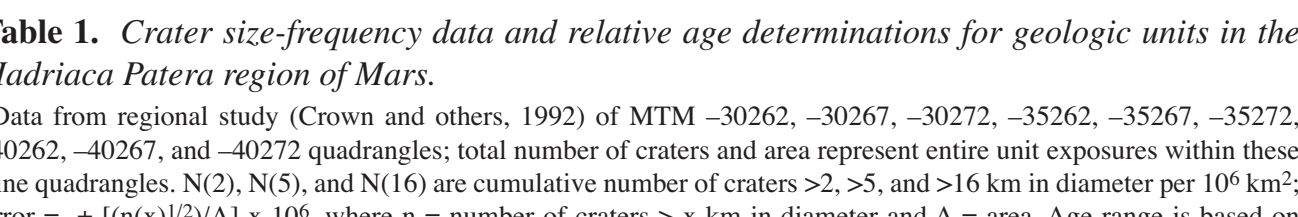

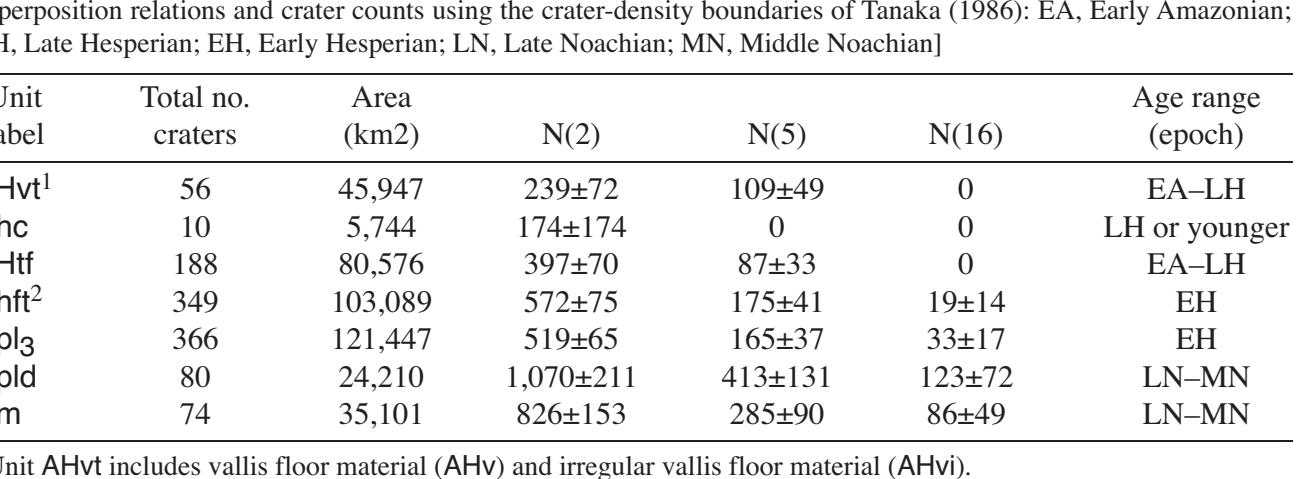

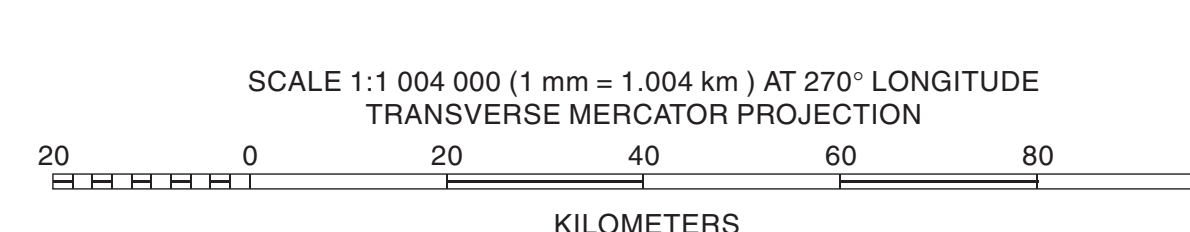

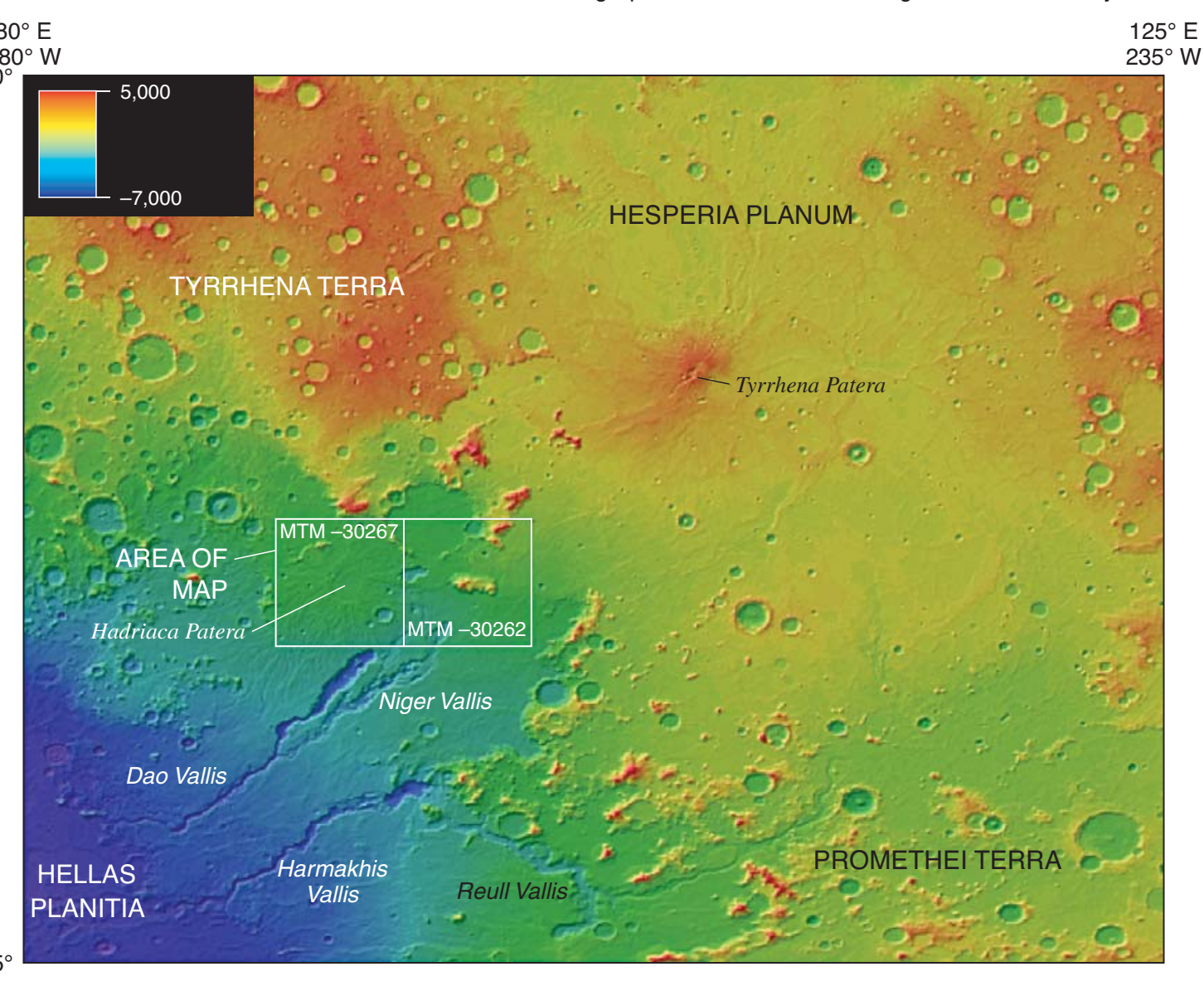

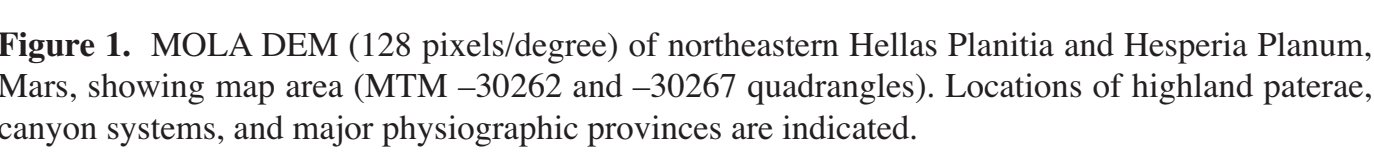

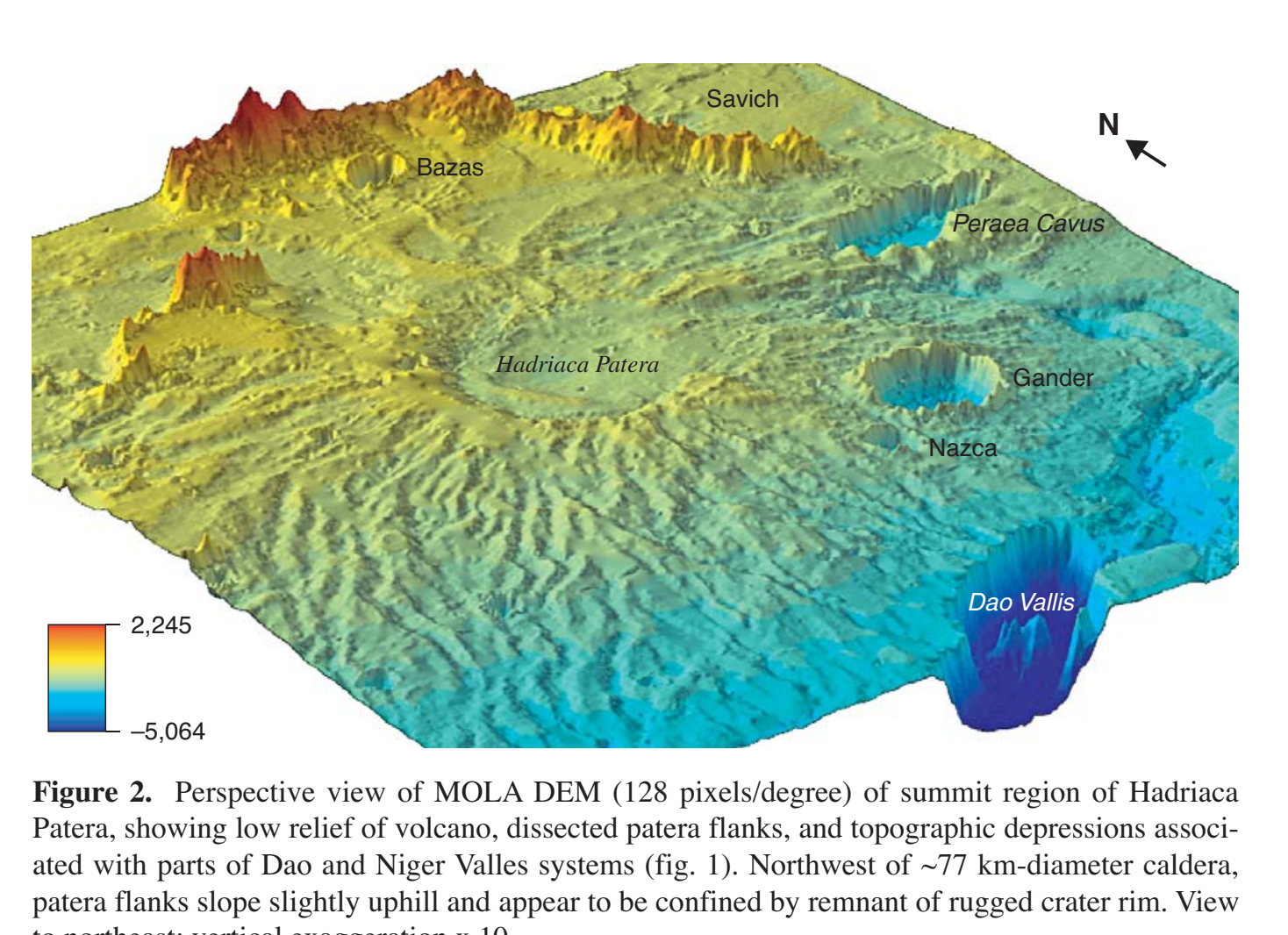

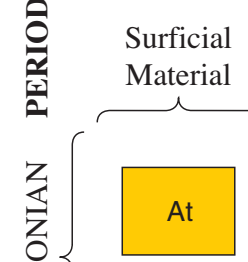

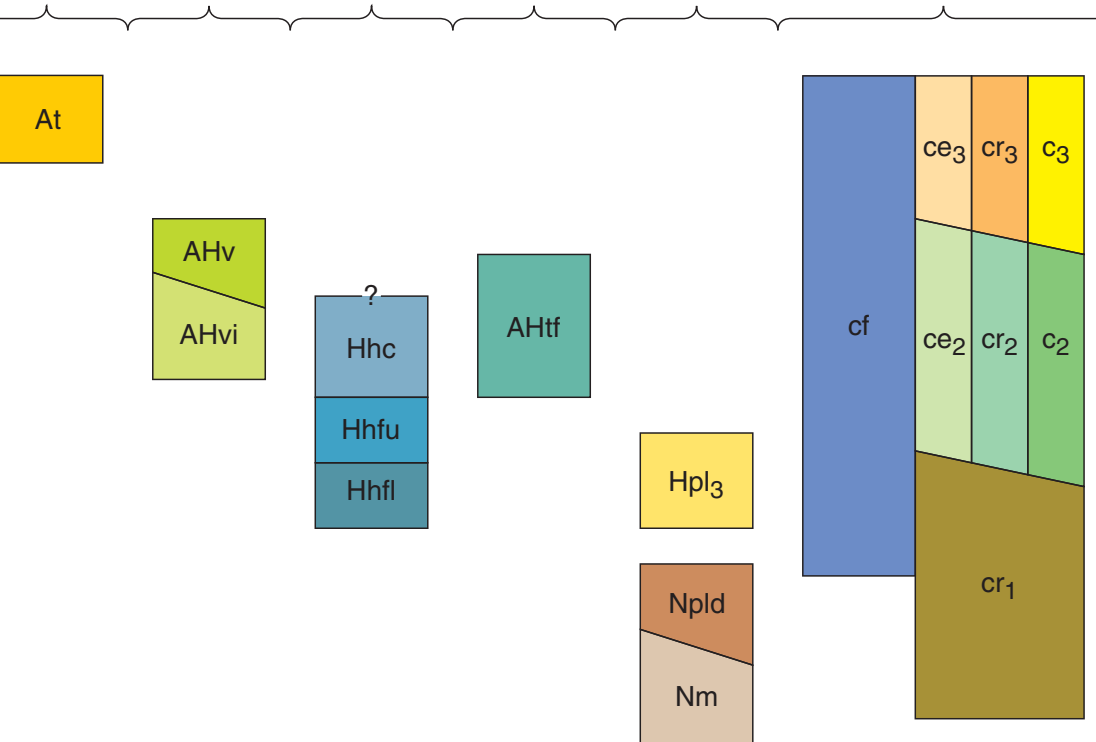

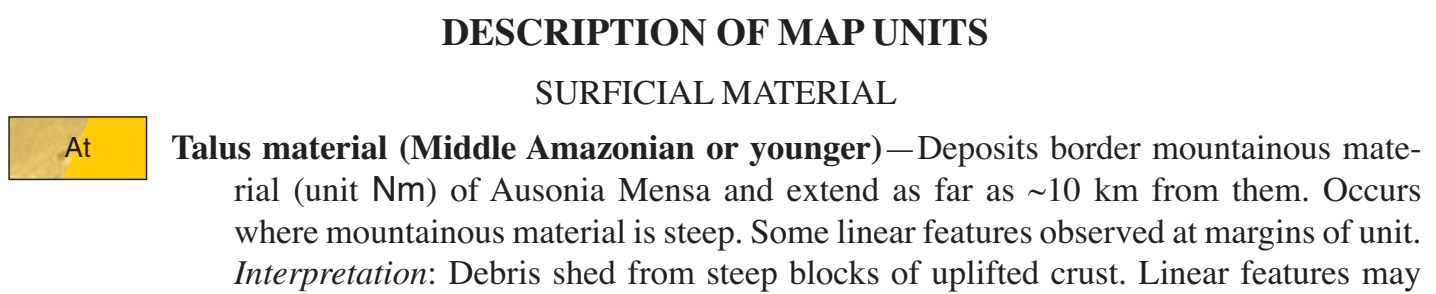

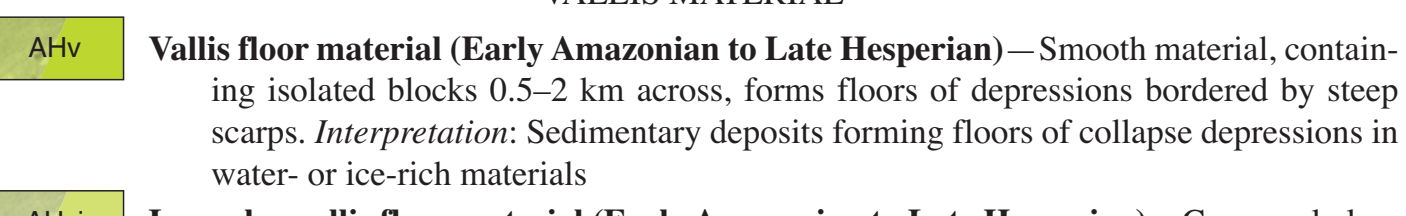

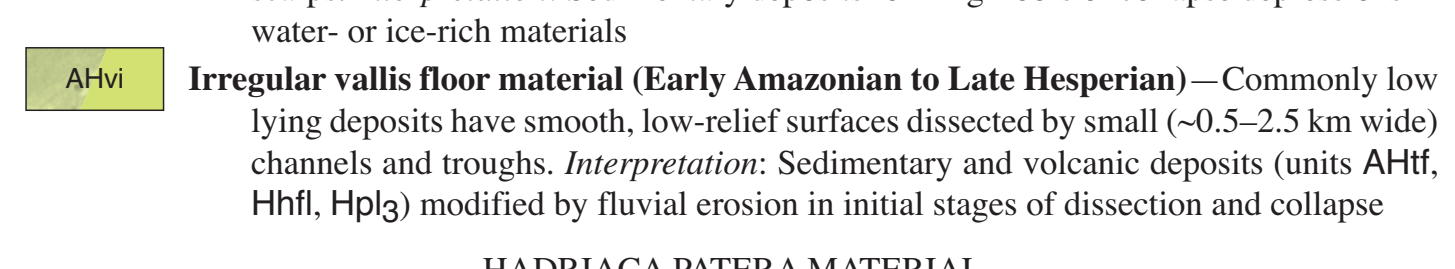

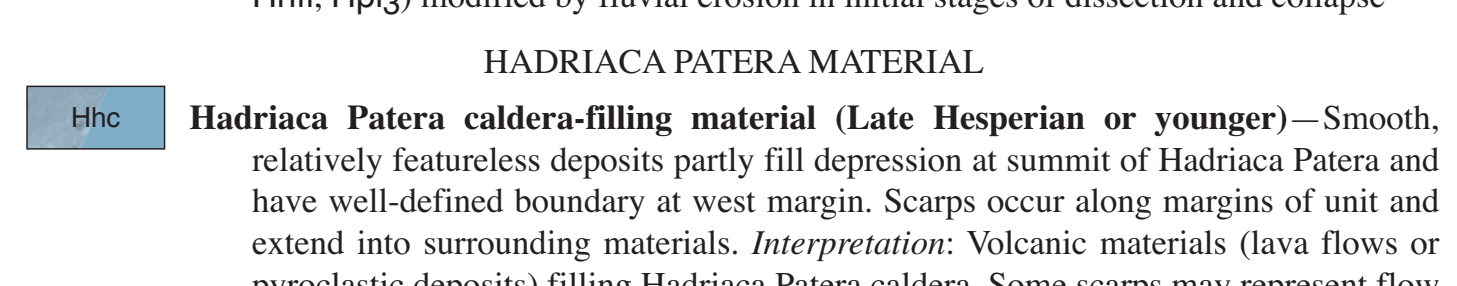

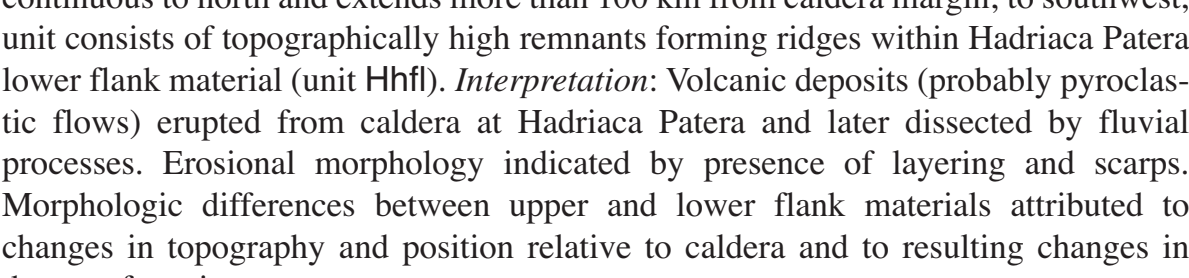

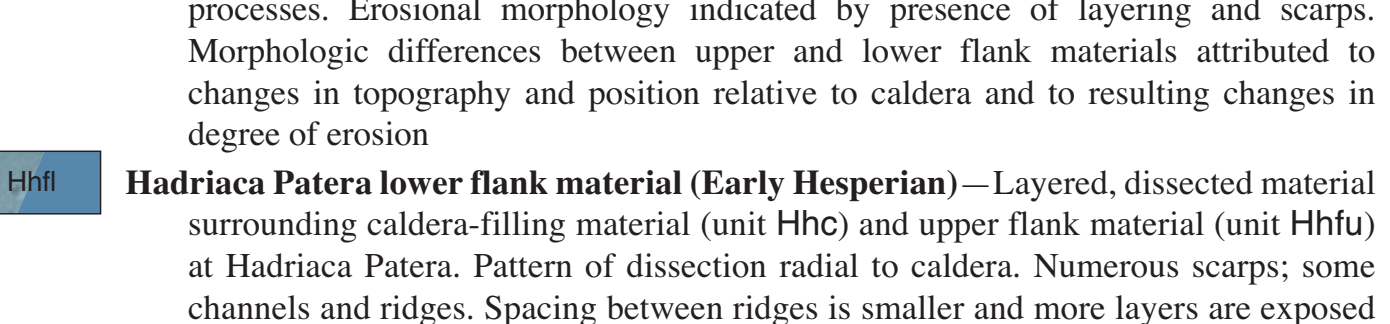

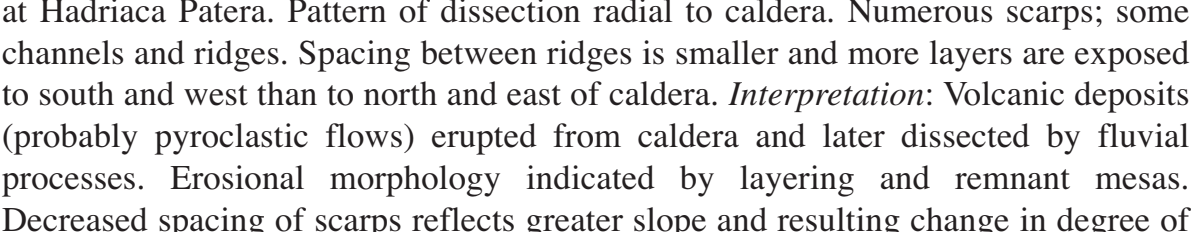

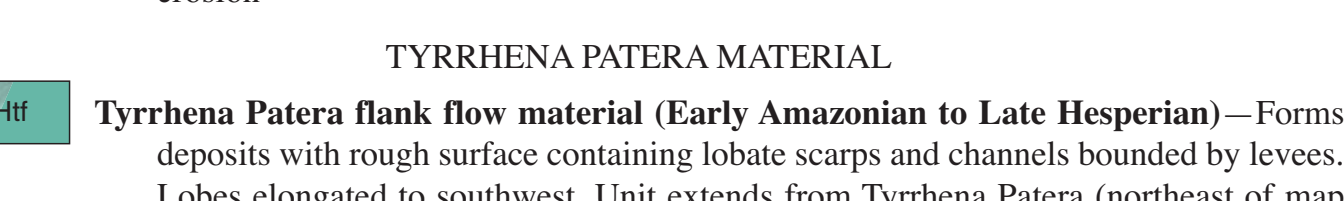

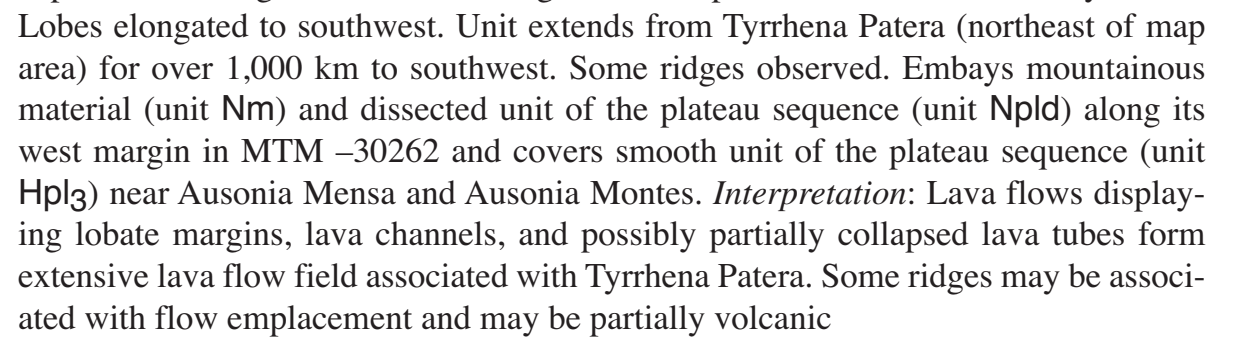

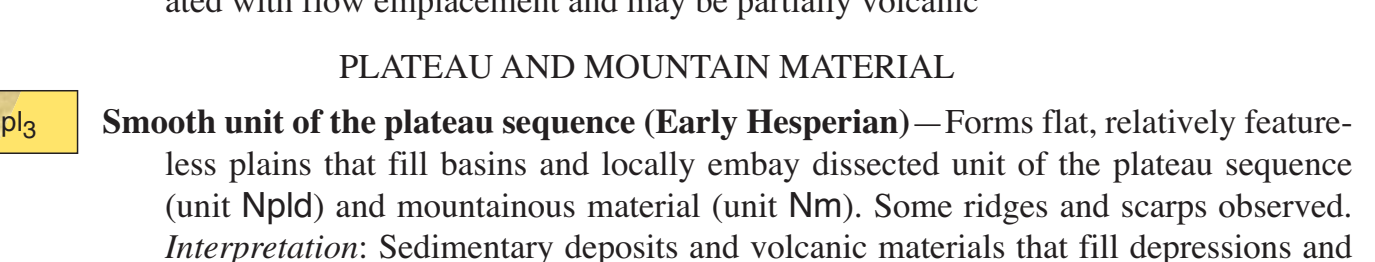

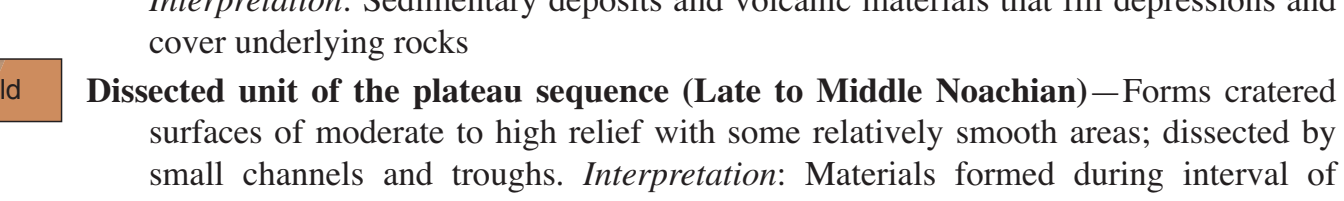

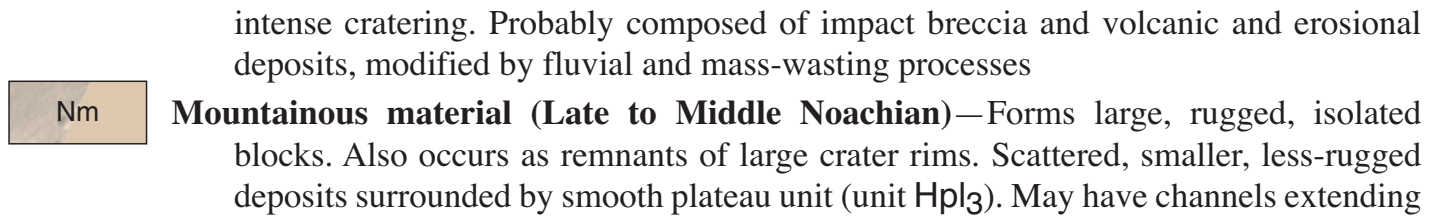

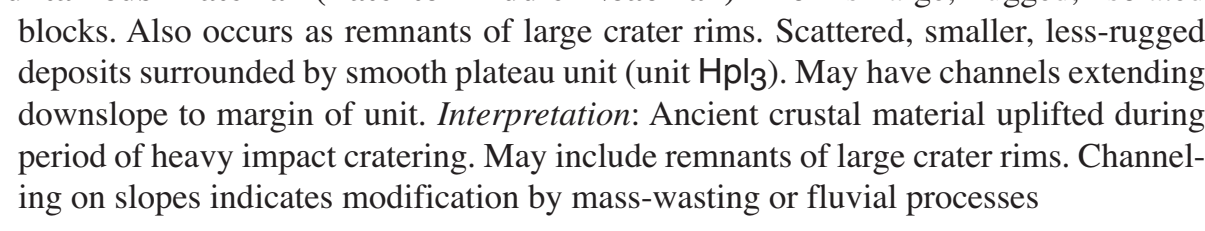

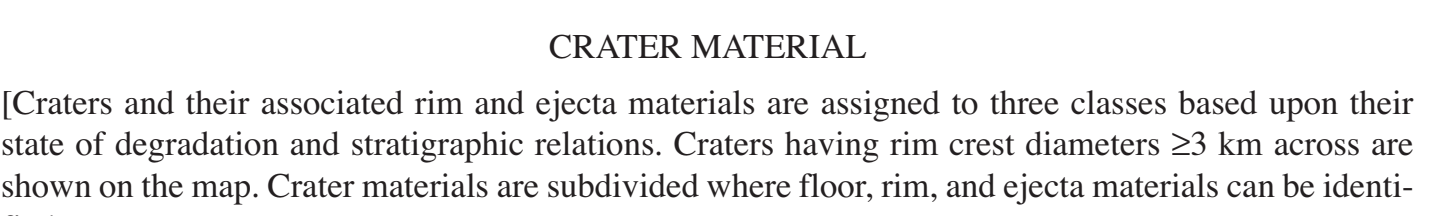

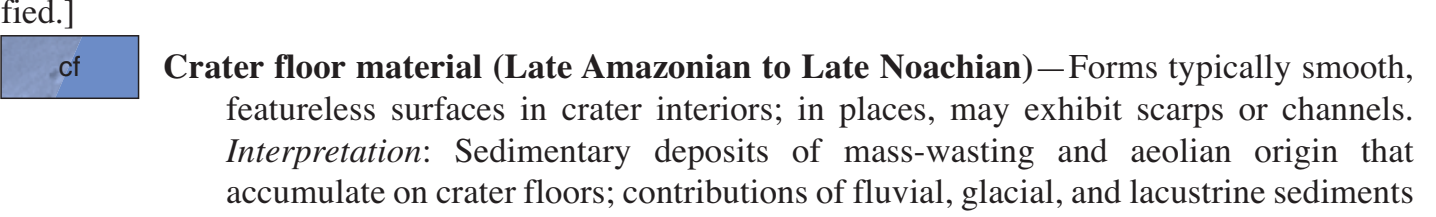

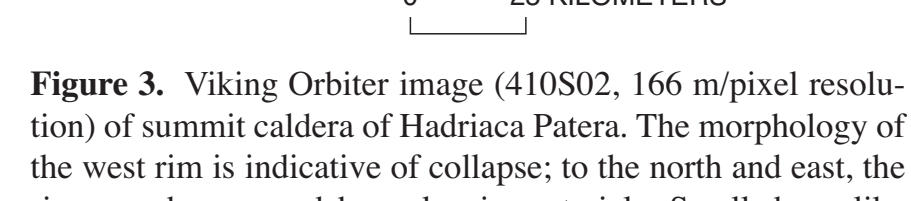

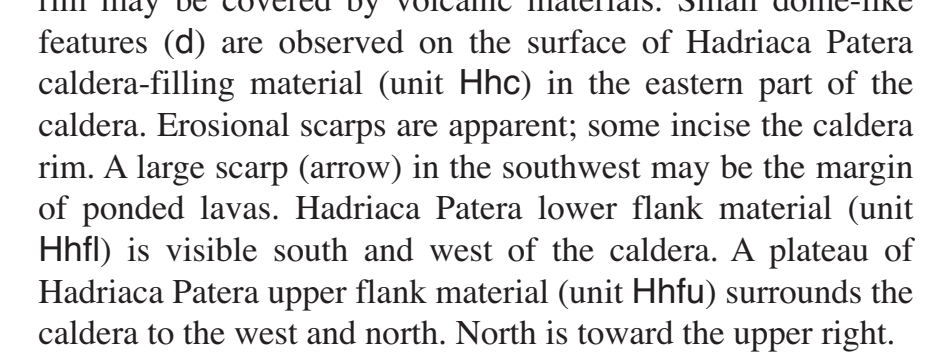

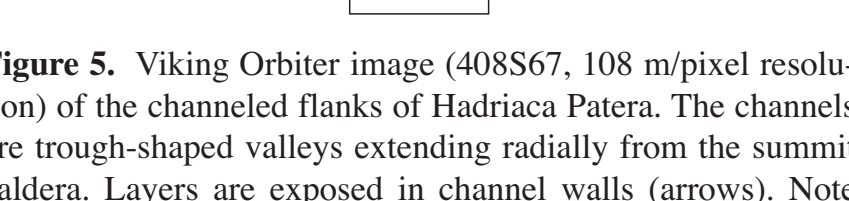

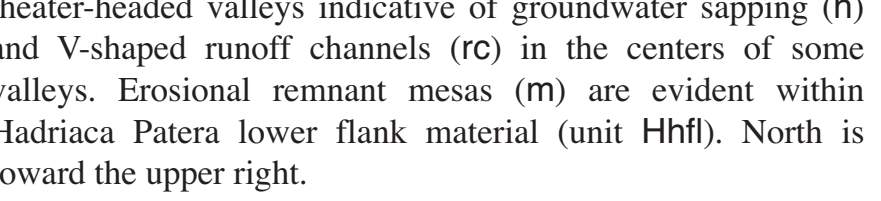

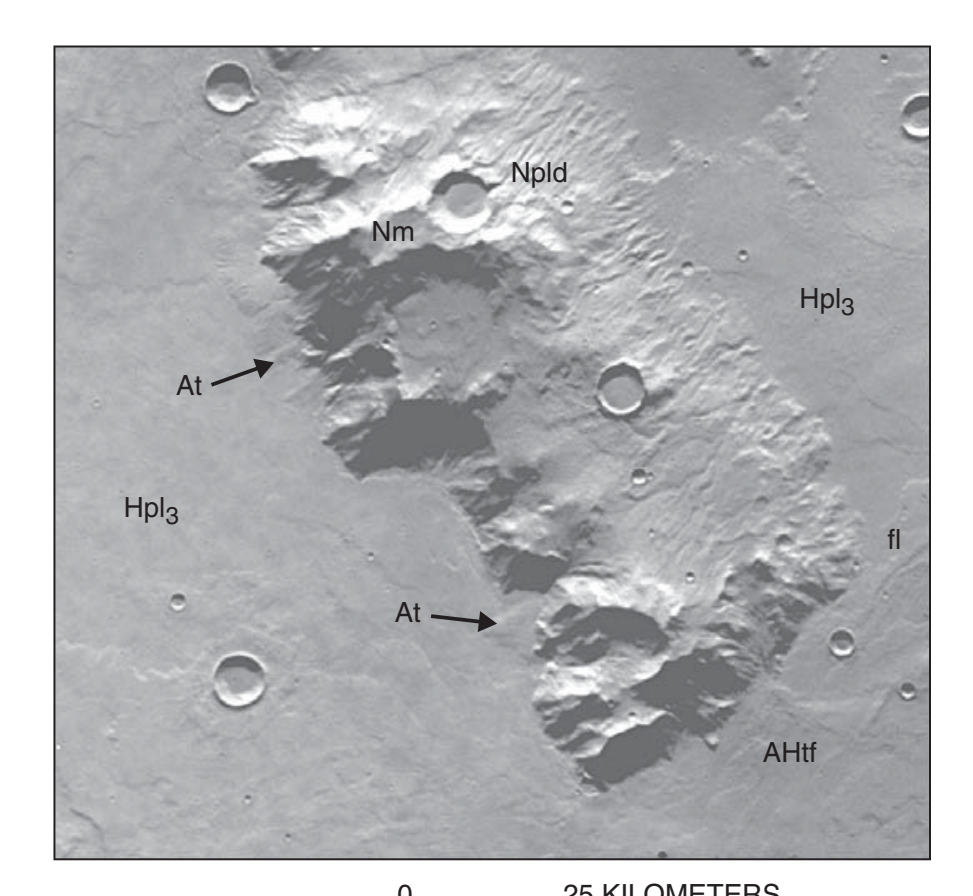

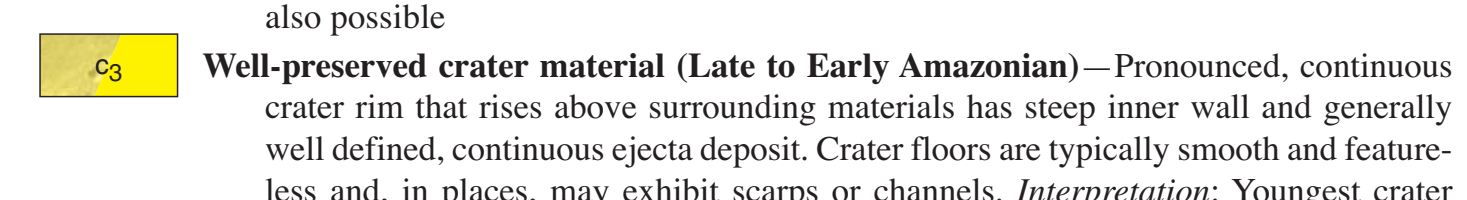

as

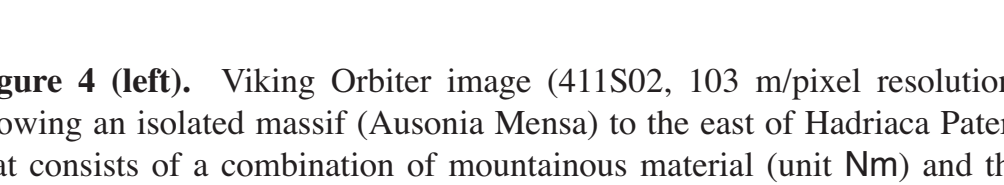

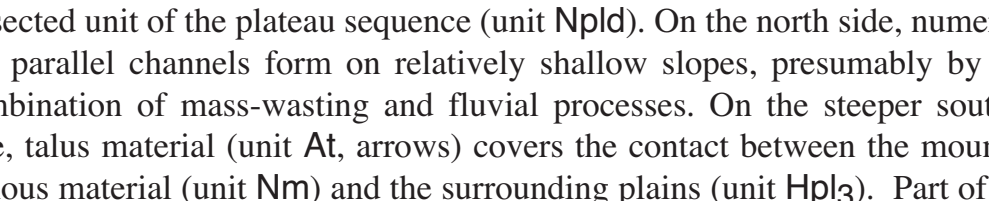

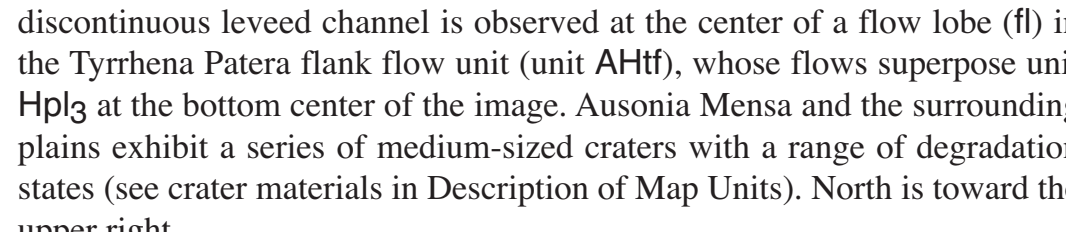

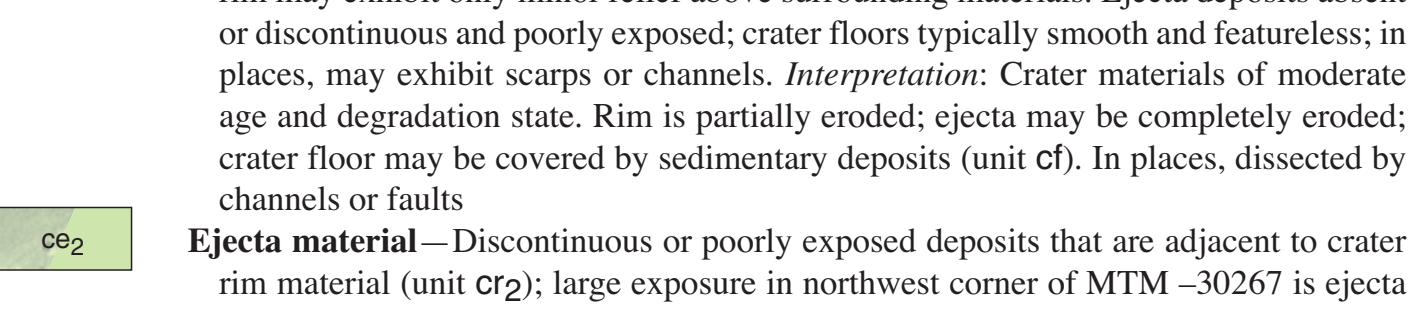

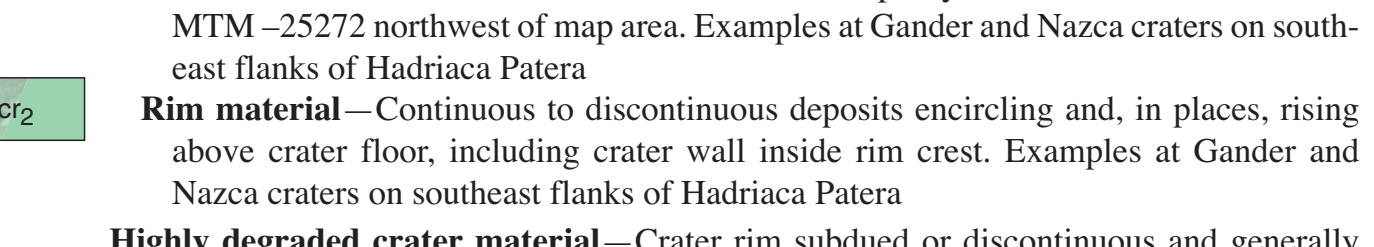

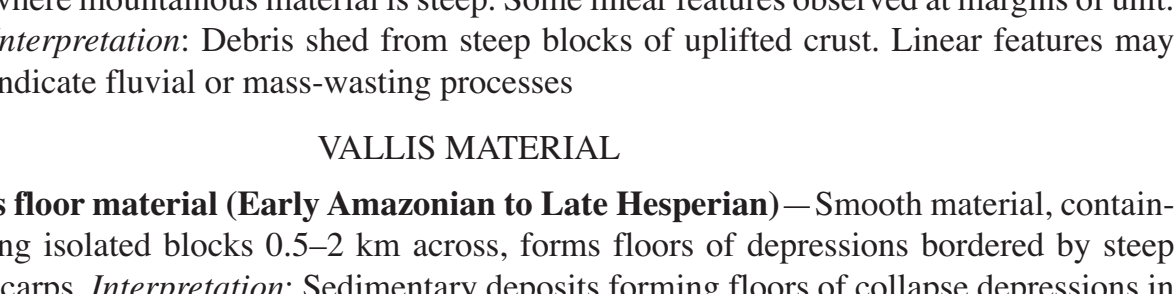

\section{Geologic Map of MTM -30262 and -30267 Quadrangles, Hadriaca Patera Region of Mars}

David A.C Crown' and Ronald Greeley ${ }^{2}$

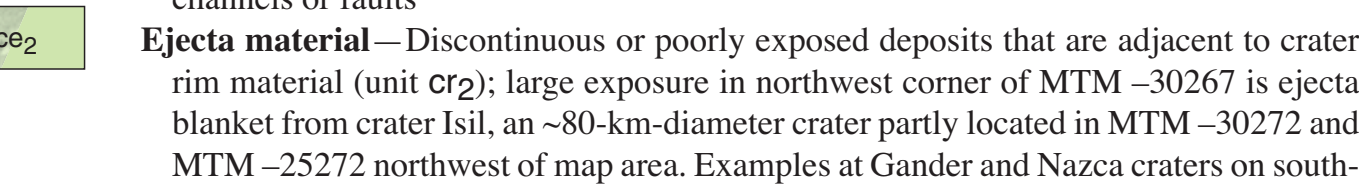

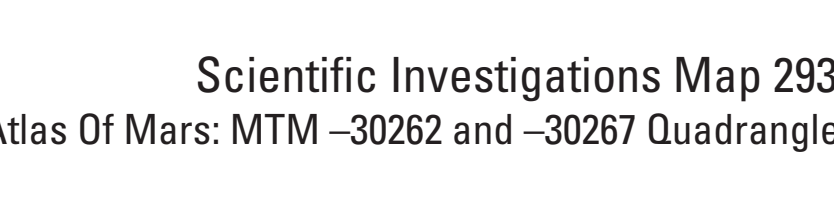

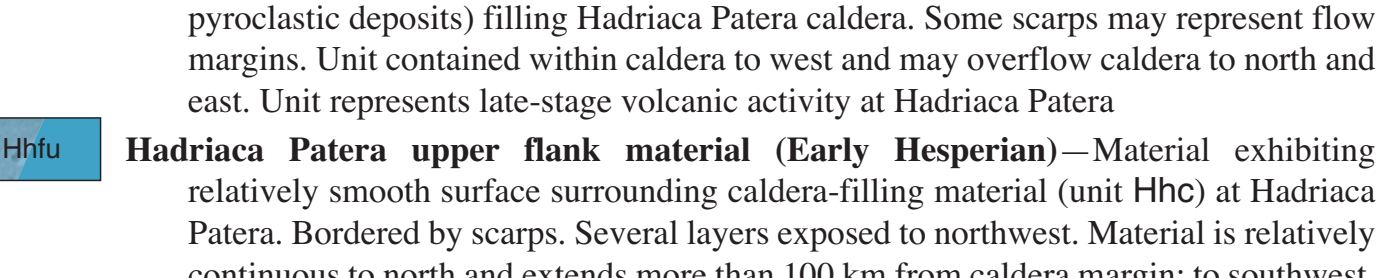

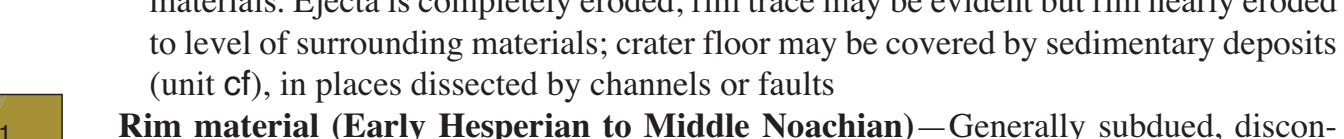

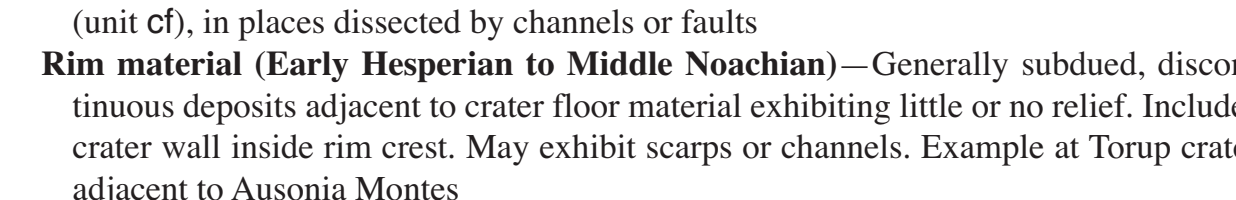

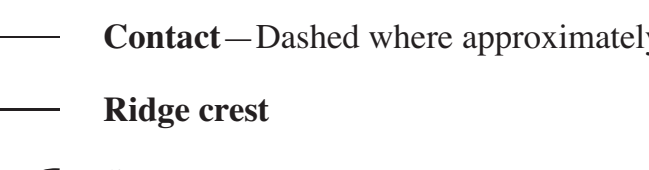

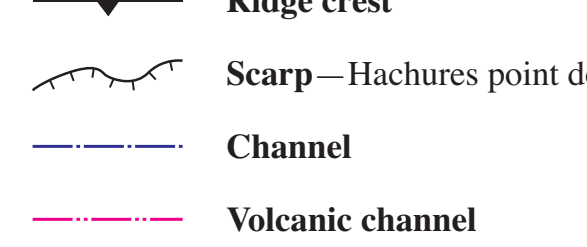

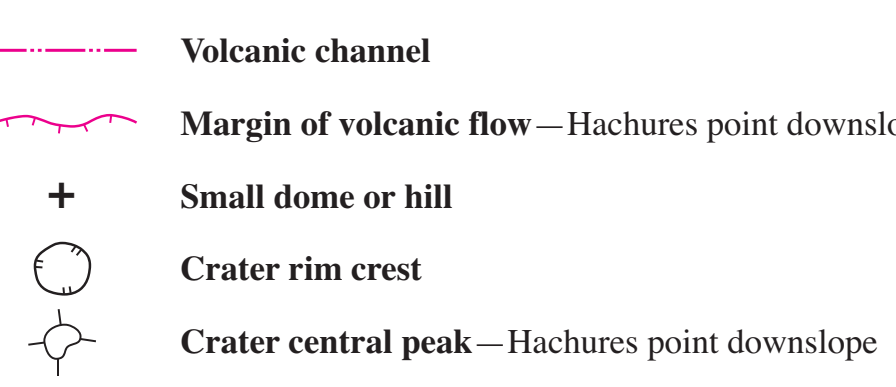

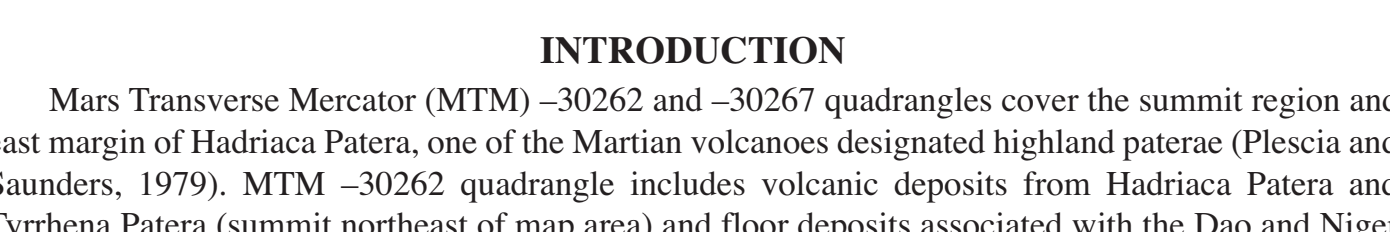

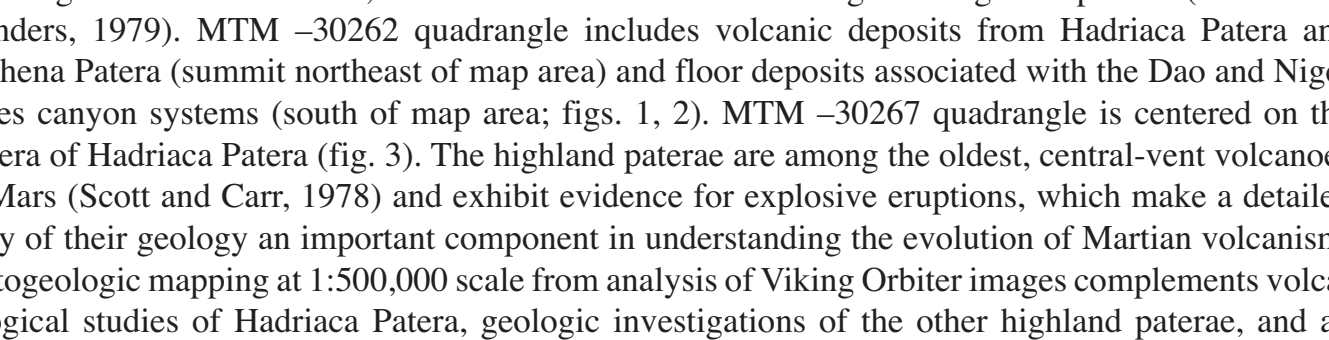

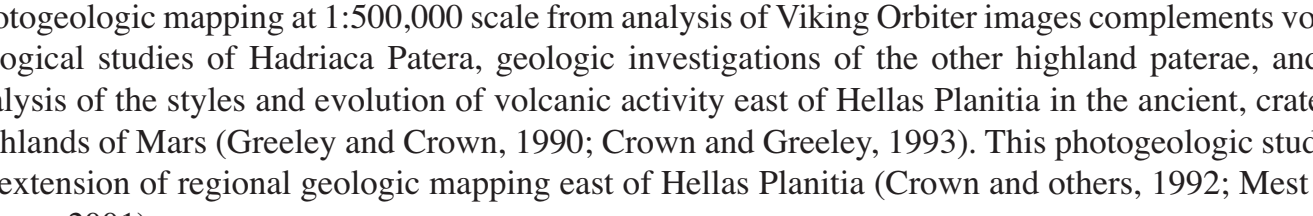

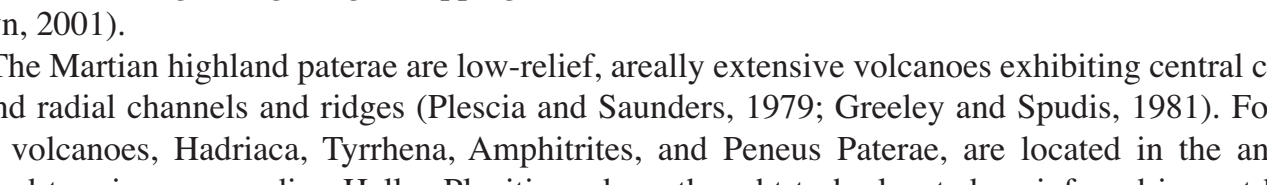
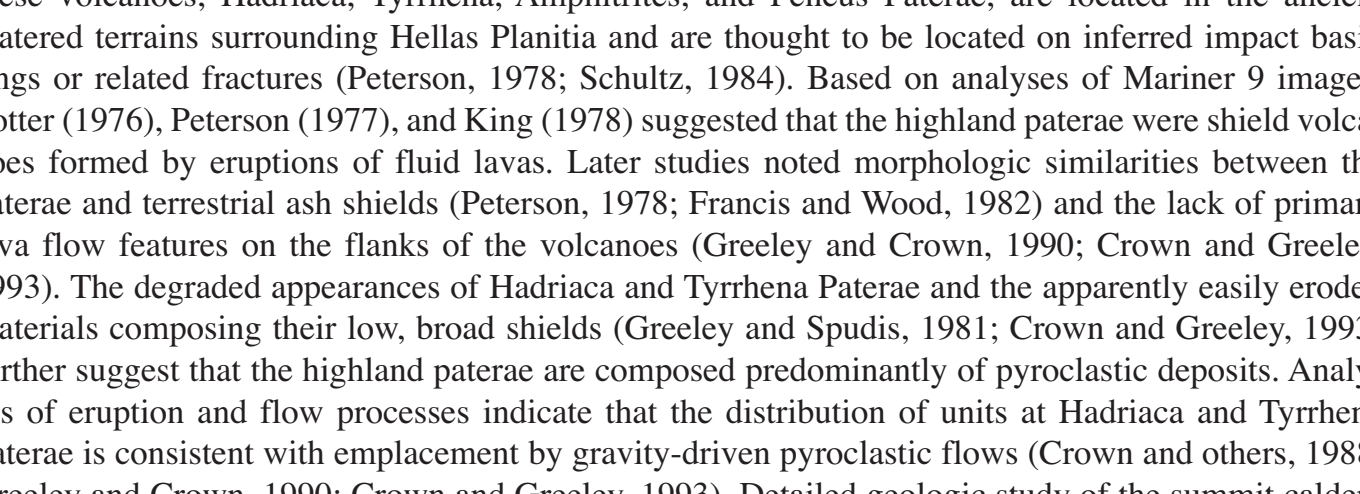

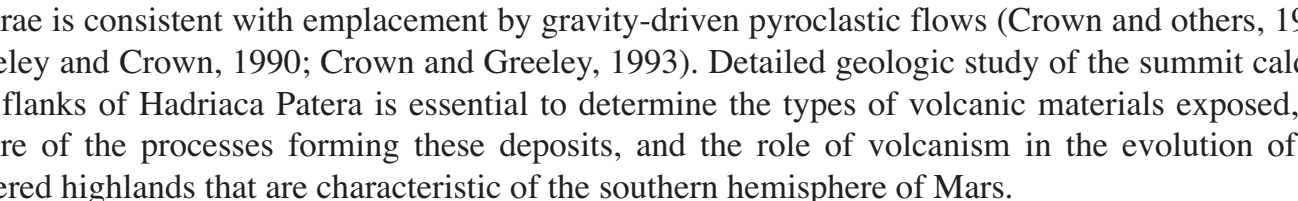

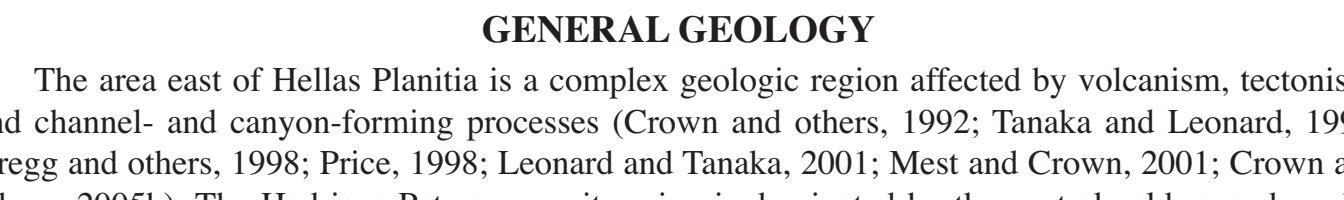
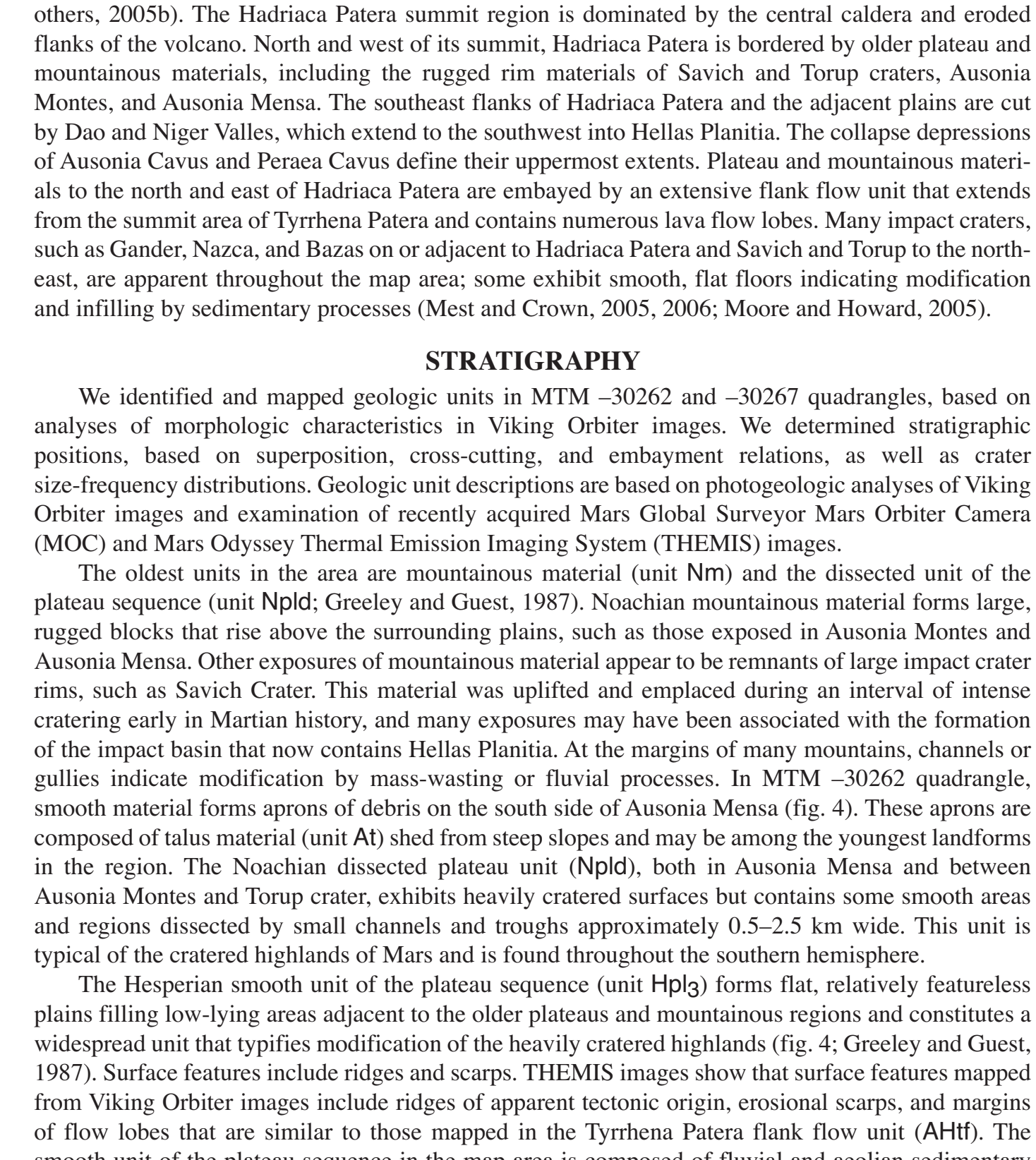

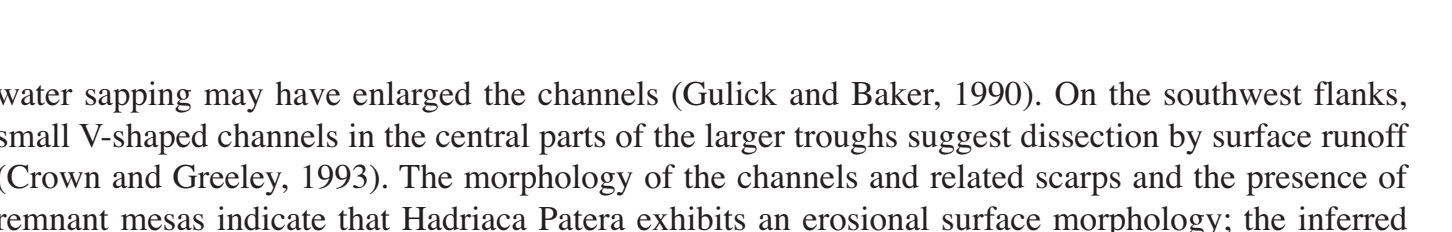

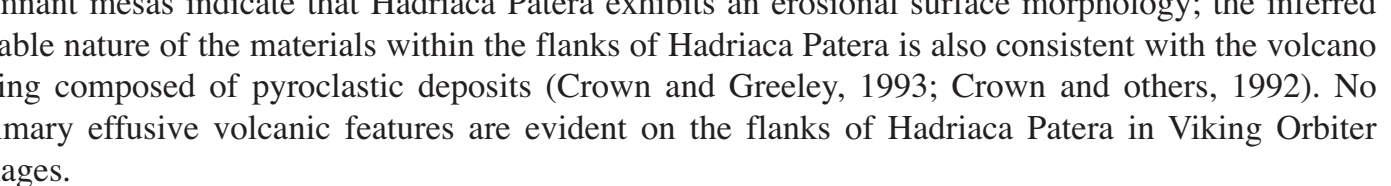

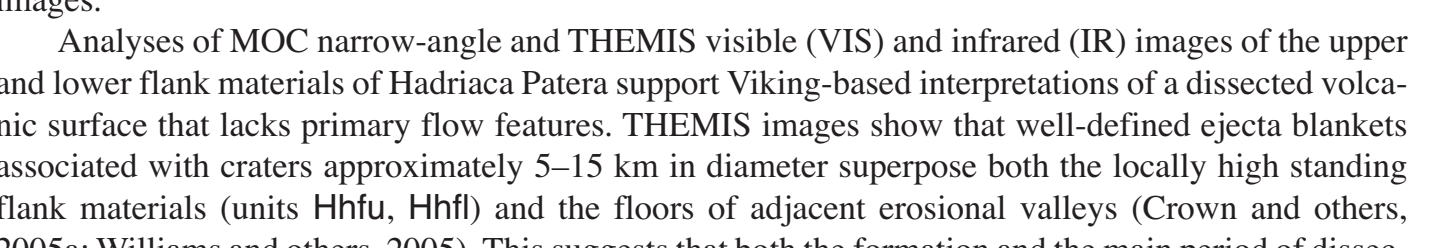

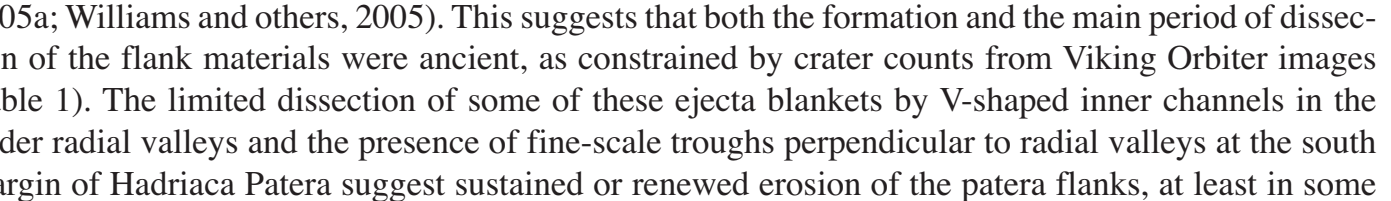

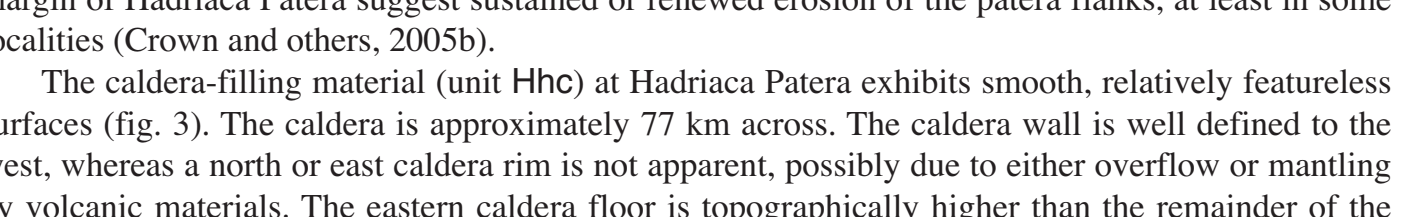

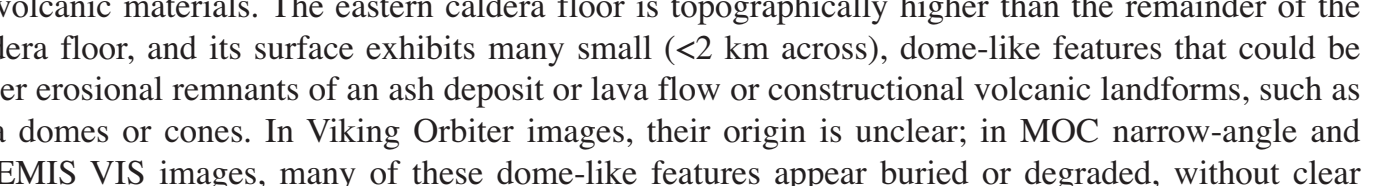

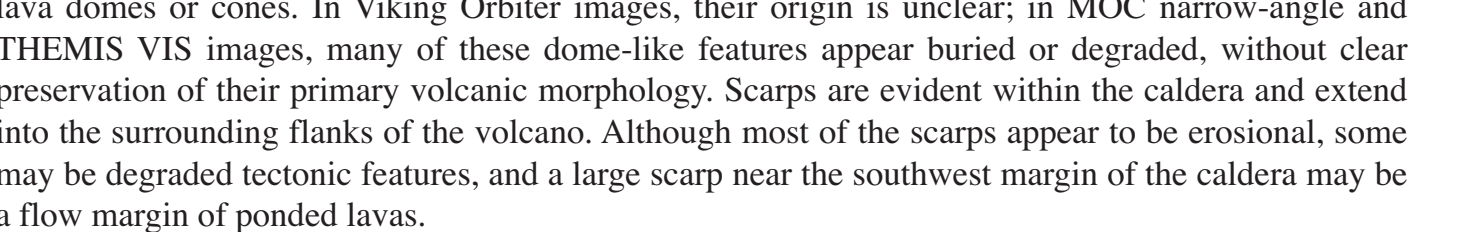

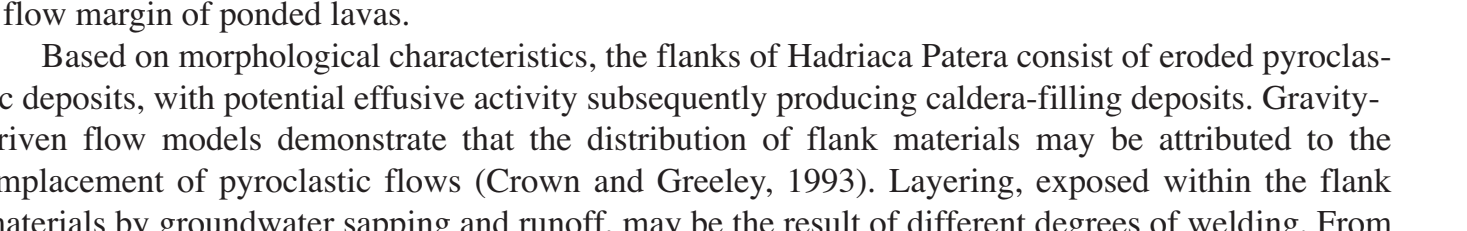

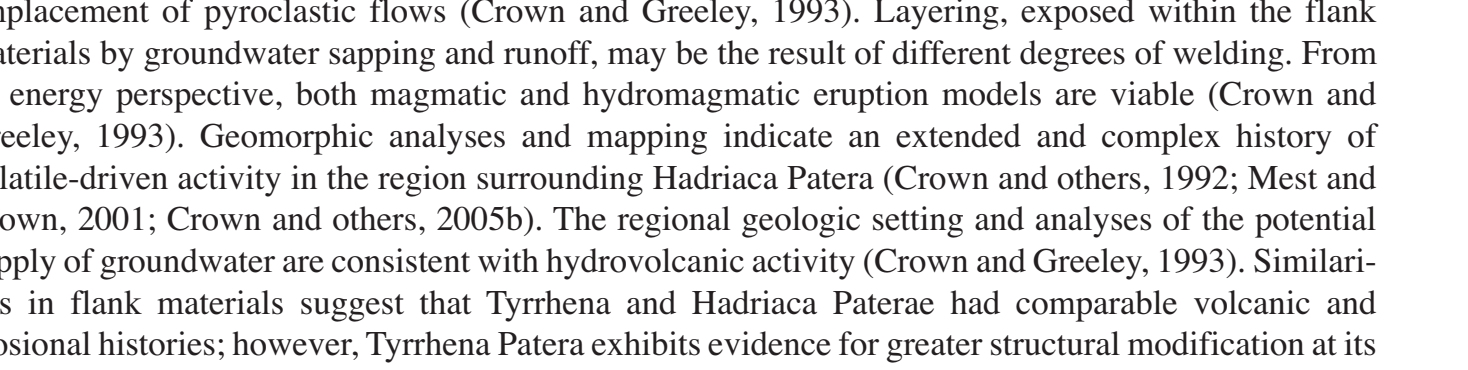

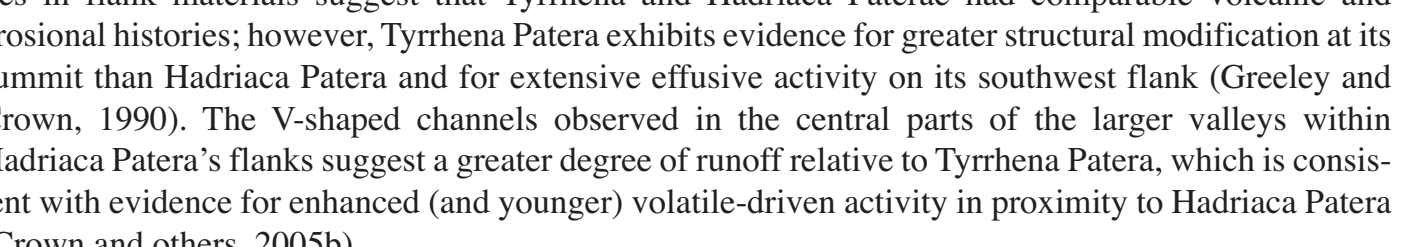

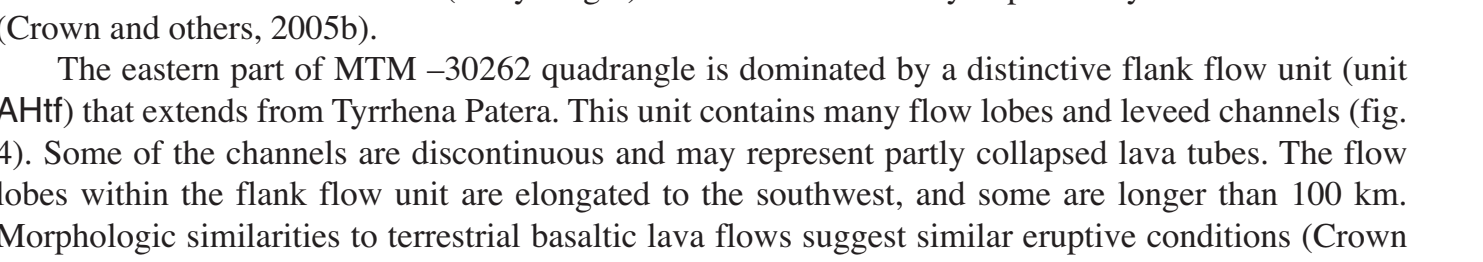

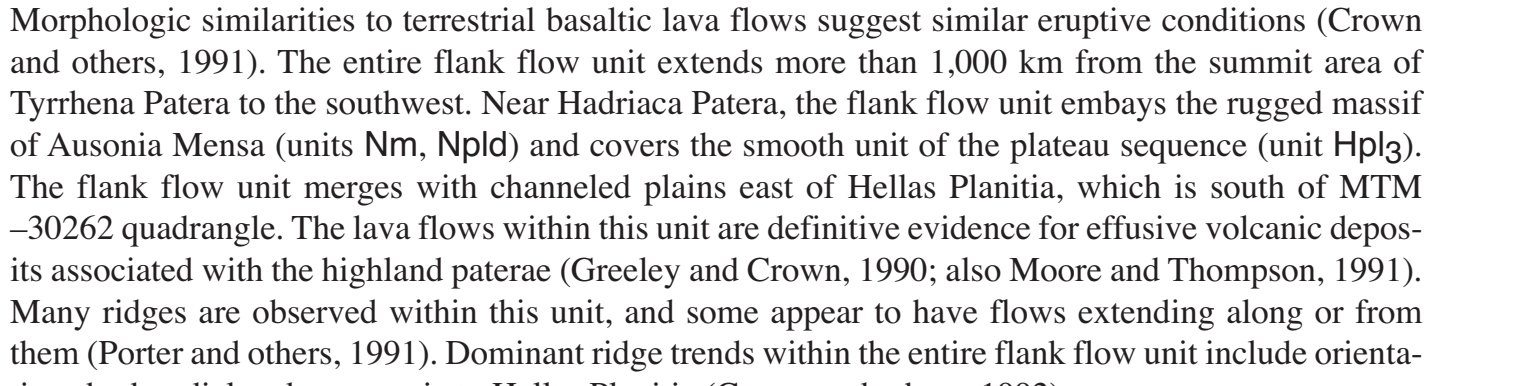

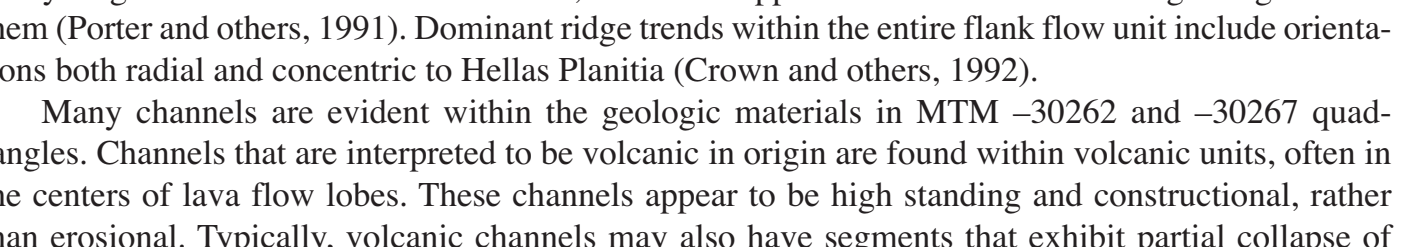

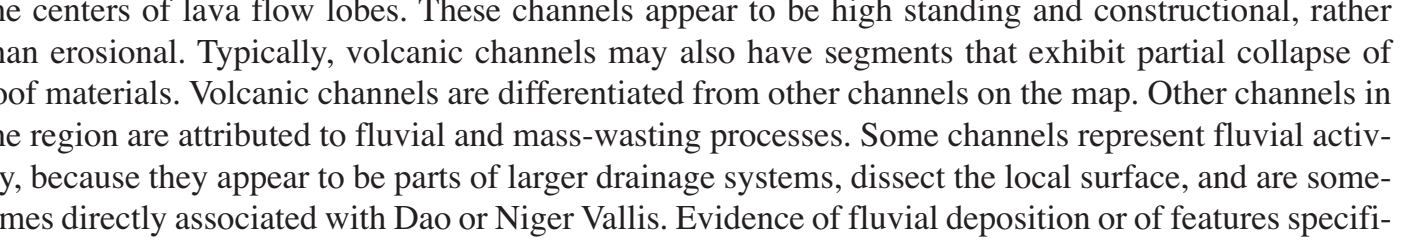

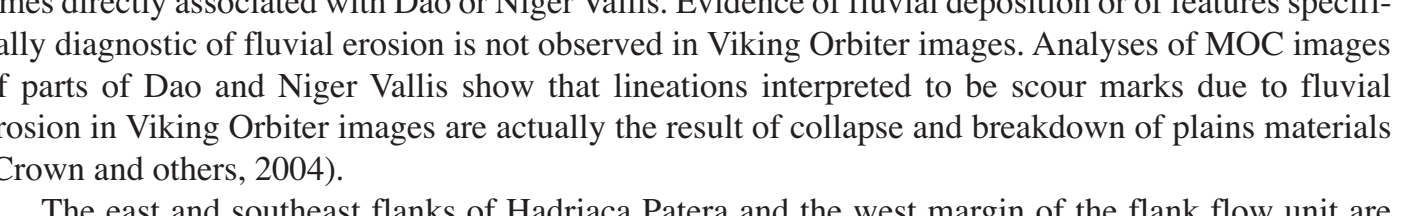

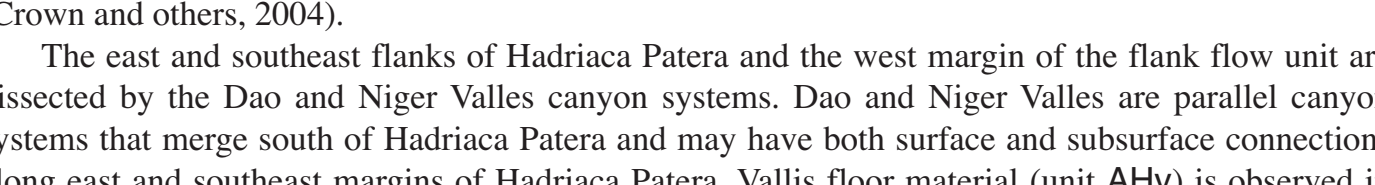

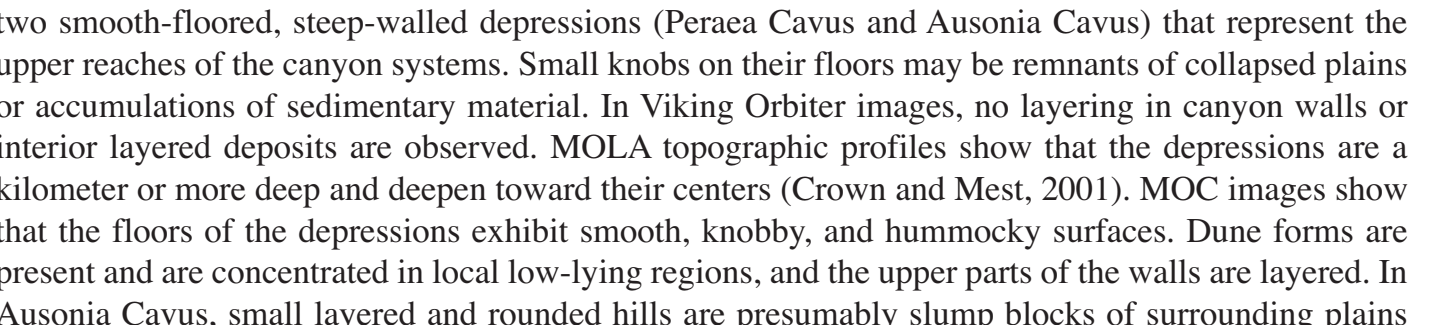

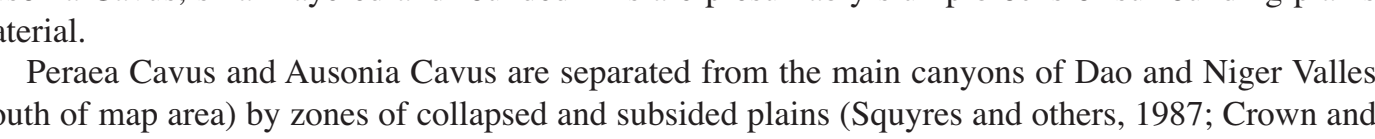

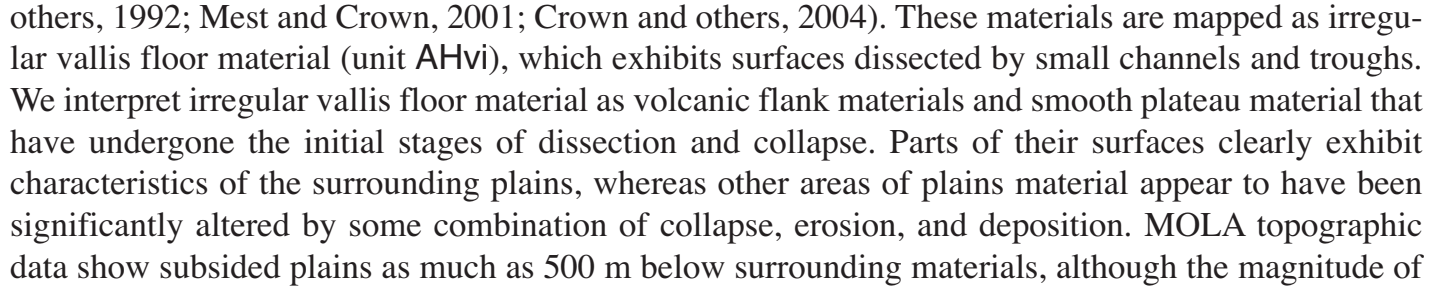

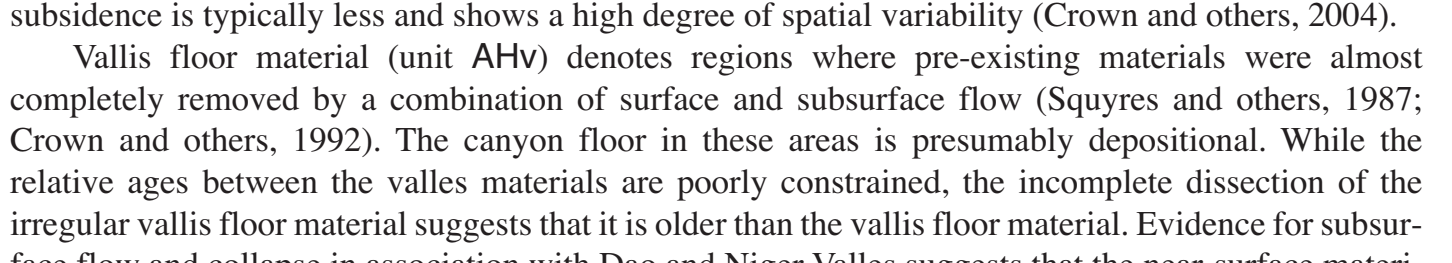

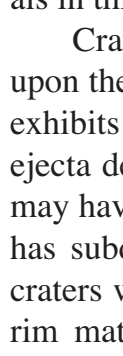

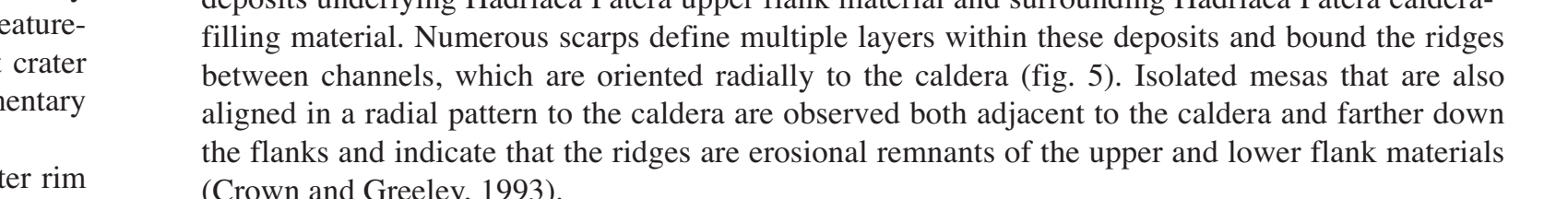

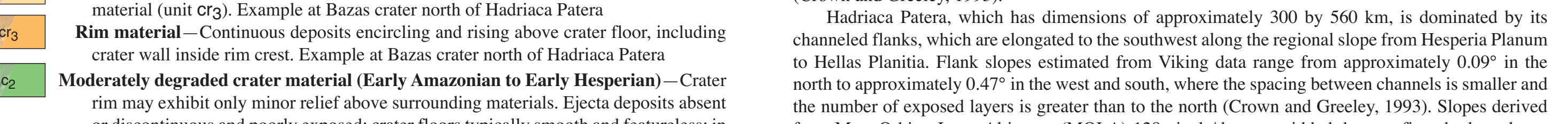

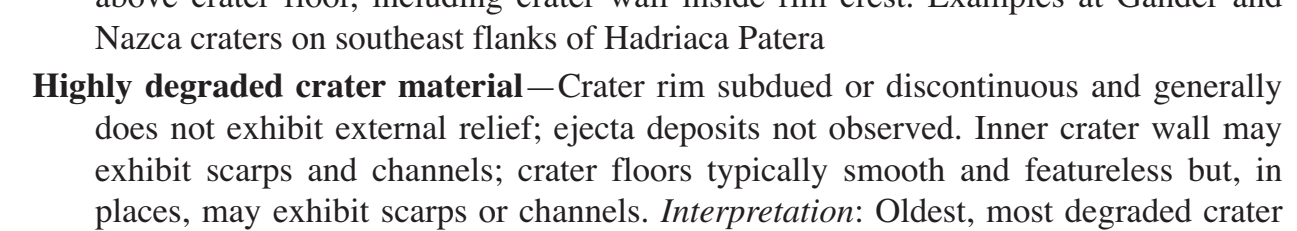

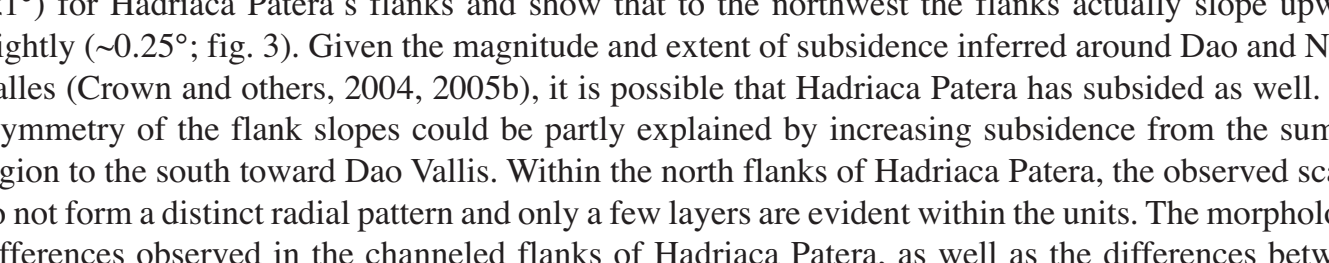

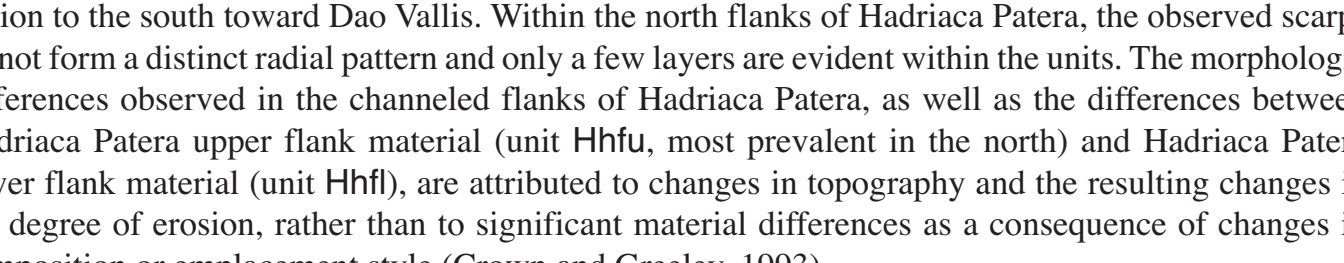

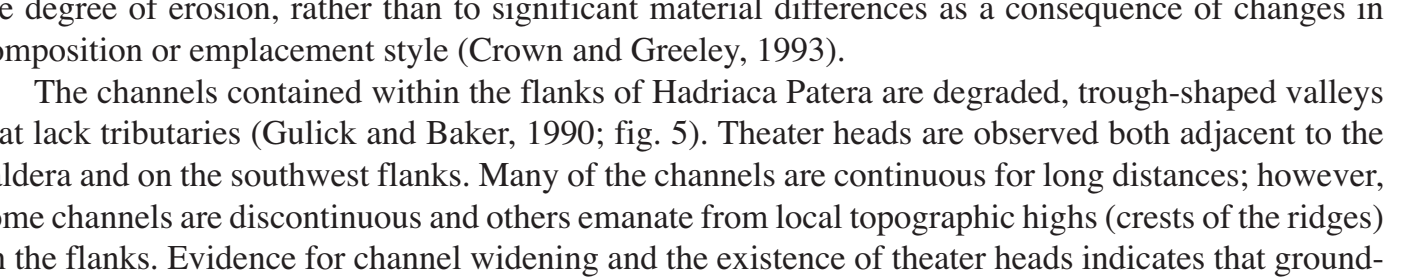

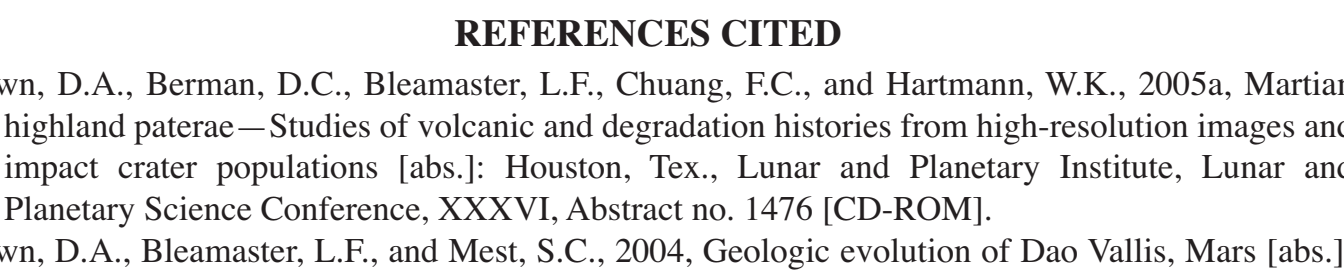

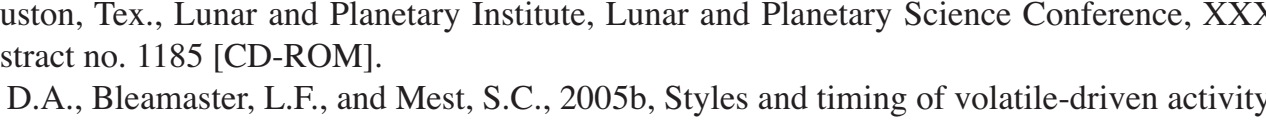

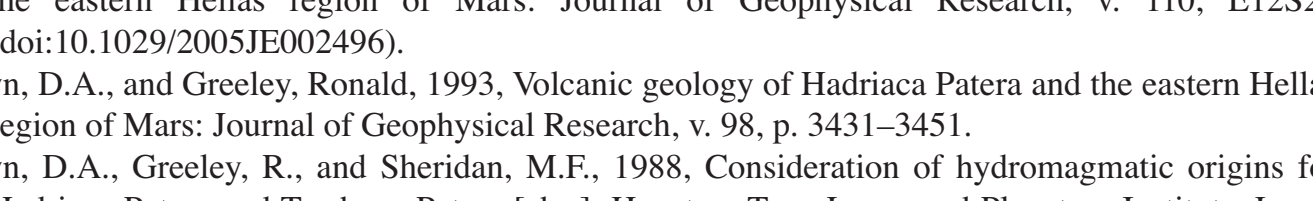

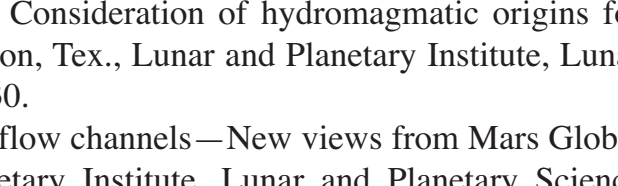

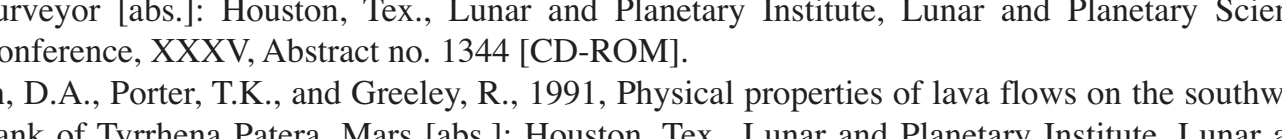

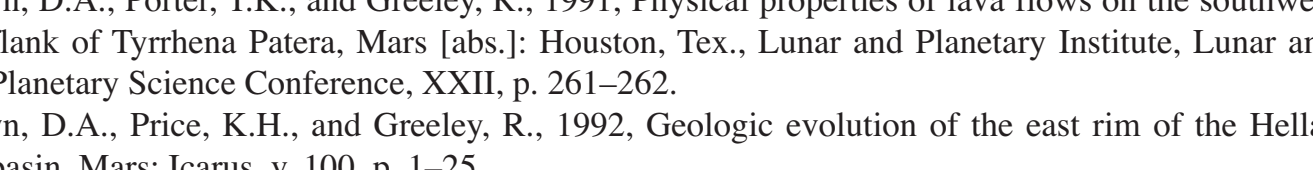

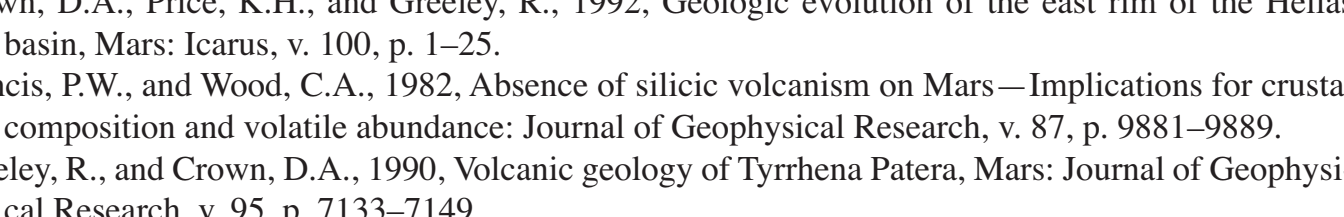

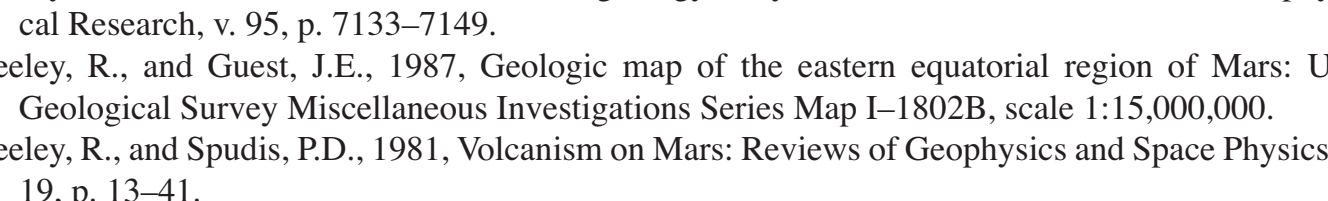

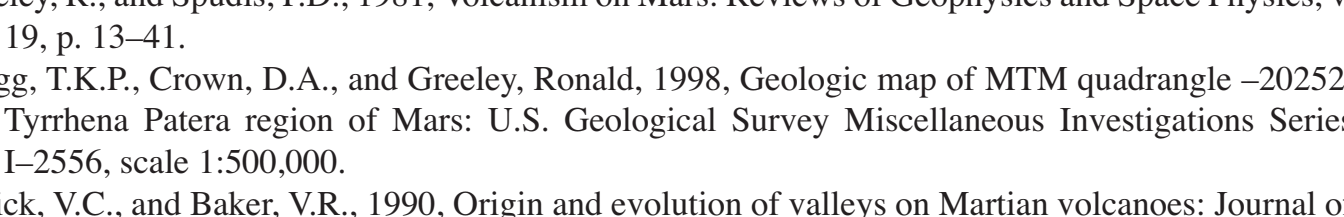

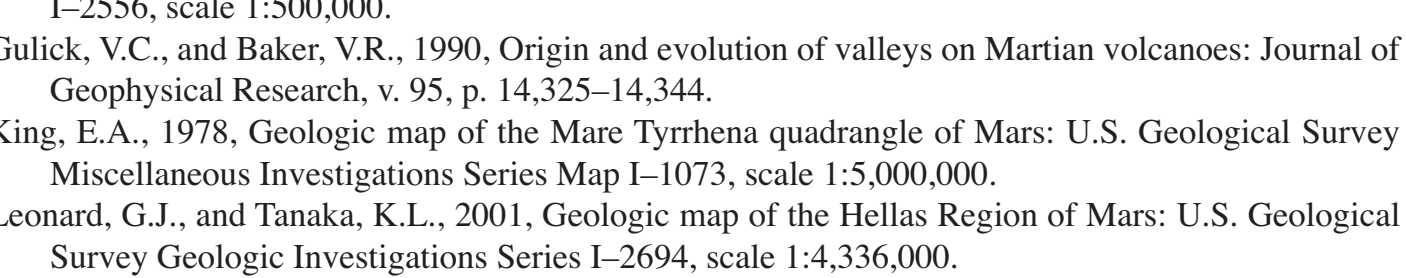

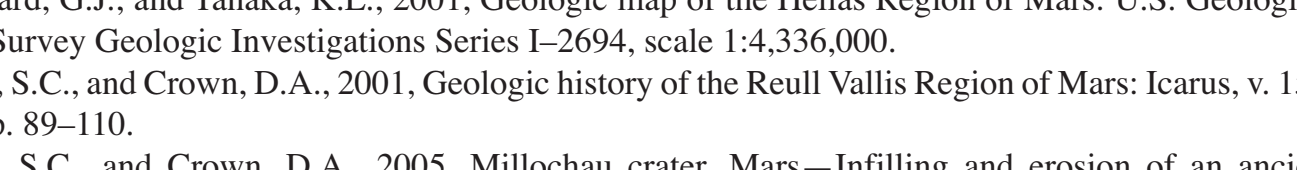

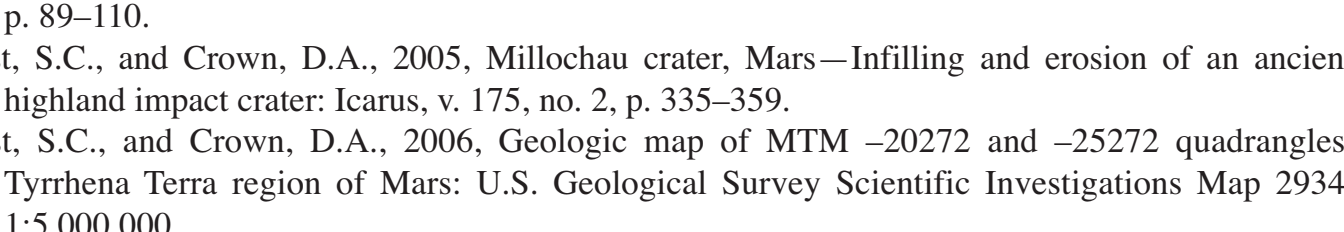

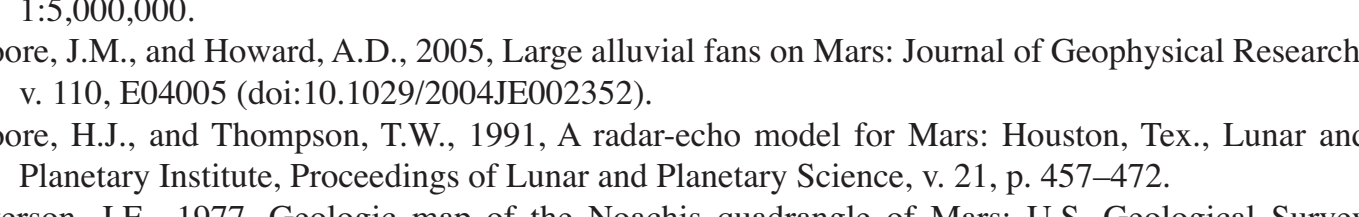

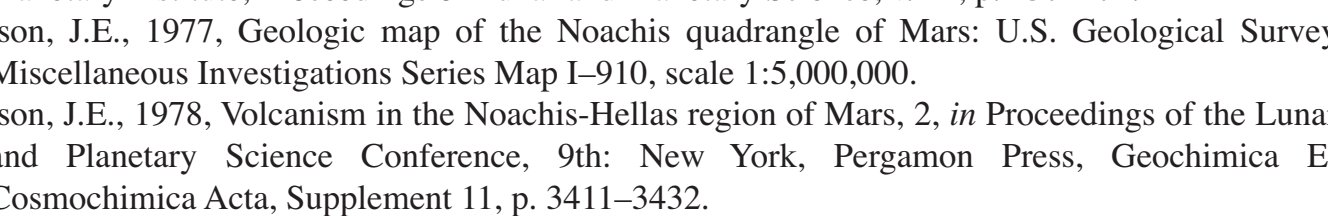

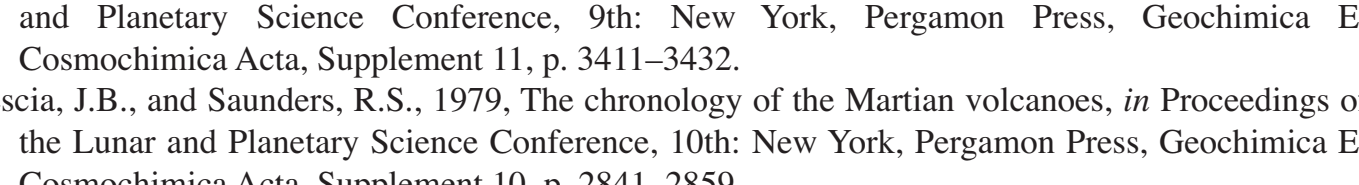

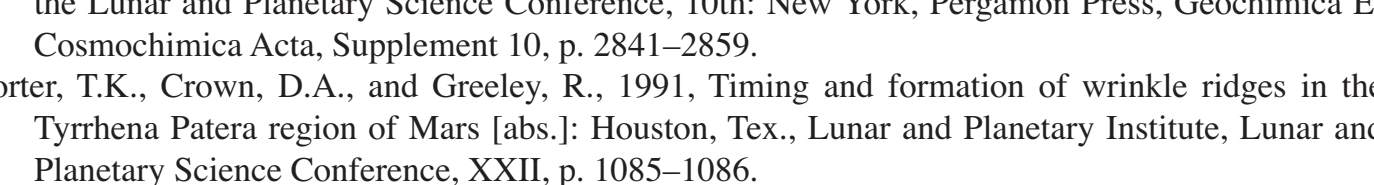

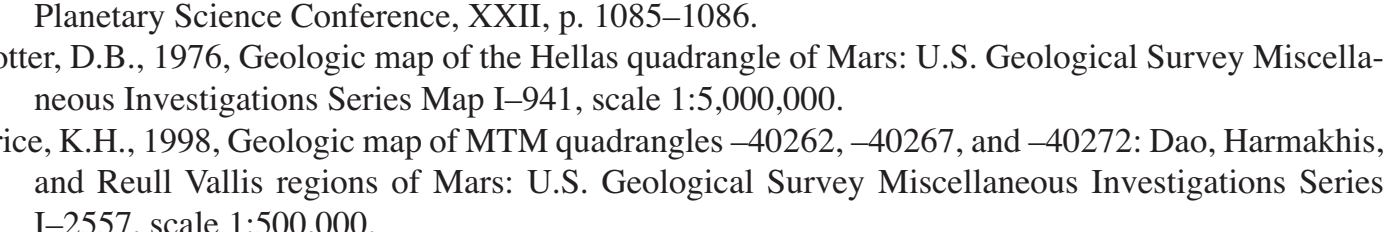

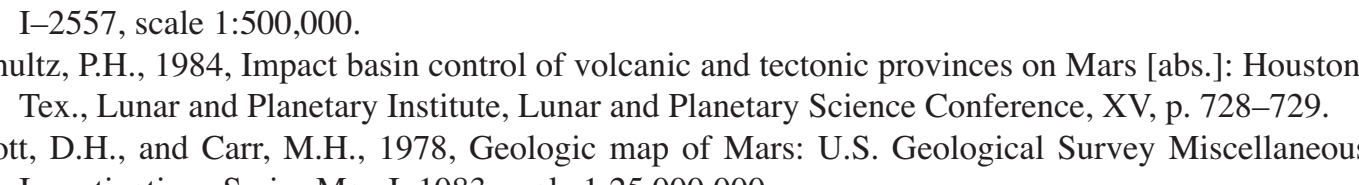

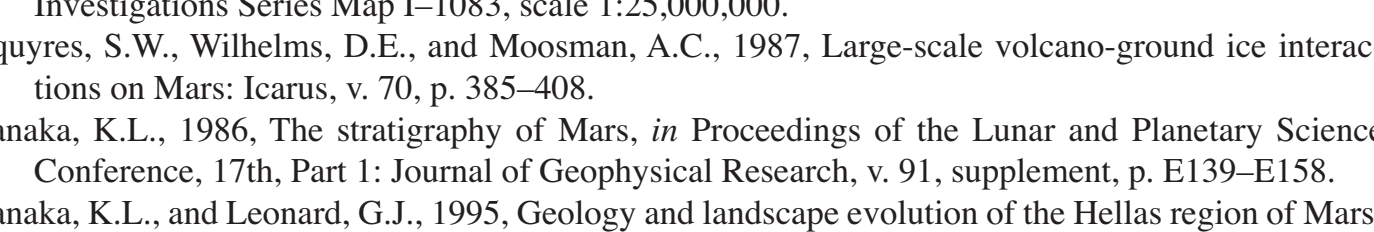

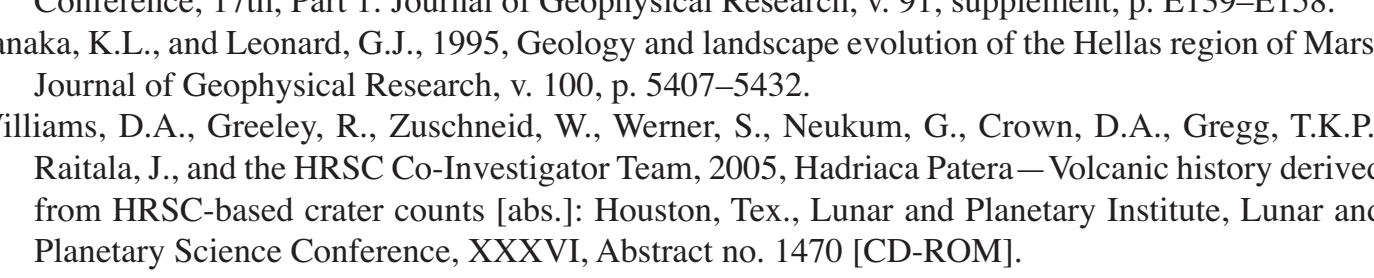

